\title{
The Interaction between Profitability and Macroeconomic Factors for Future Examinations of European Banks Soundness - Theoretical Study
}

\author{
Nahidah Naser \\ Cracow University of Economics, Inter-Faculty PhD Studies in English, Poland
}

\begin{abstract}
Any weakness in the financial institution is subject to the contagion mechanism. As result, the whole financial system will experience unpredictable financial risks and possible crisis, such as to a systemically relevant institution (e.g. Lehman Brothers' default, 2008's financial crises and Asian financial crises). The contagion mechanism (Quagliariello, M., 2009 [1] (Trapanese, M.) is a crucial element in the assessment of the crossborder dimension. The direct cross-border contagion risks (idiosyncratic risks) are: risks related to crossborder interbank links; money markets and cross-border ownership links; common shocks of foreign economies and global financial markets that can affect banks' exposures due to changes in credit quality, market valuations and funding costs. Secondly, the indirect cross-border contagion risks (Indirect contagion) are caused by systematics risks that exclusively related to cross-border credit exposures (e.g. lending to nonfinancial institutions, credit risk transfer exposures as well as international syndicated lending), market risk exposures (by holdings of securities and off-balance sheet positions), common cross-border funding (by financing through market instruments and operational risk).

From a theoretical point of view, said institutions are defined as risky banks, have unpredictable impacts on the smoothness of whole financial system. Moreover, these credit, market and liquidity risks represent the main triggers of crises. This paper is the second part of my theoretical study focused on the profitability and the soundness of European banks with an emphasis on the role of the Macro profile. In this paper, I also thoroughly investigated the macroeconomic determinants used to predict the Banking crises. Moreover, this paper analyzed the history and behavior of European banks during financial crises, and the corrective measures taken by authorities, governments and supervisory institutes to bail out the troubled banks, or to support the banking system as a whole. An extensive assessment of collected data resulted in detailed analysis of quantitative methodologies as well as the examination of the effectiveness of selected macroeconomic determinants to avoid the financial instability. This study shows that the macroeconomic adjustments were called upon during the crises.
\end{abstract}

Keywords: bank profitability; soundness of banks, inflation, GDP, interest rates, macroeconomic determinants, Moody's rating, exchange rates.

JEL classification: G21; G24; G01; E40

(C) The Author, 2019. This article is published with open access at Sumy State University.

Cite as: Naser, N. (2019). The Interaction between Profitability and Macroeconomic Factors for Future Examinations of European Banks Soundness - Theoretical Study. Financial Markets, Institutions and Risks, 3(3), 63-97. http://doi.org/10.21272/fmir.3(3). 63-97.2019.

\section{Introduction}

A stable macroeconomic framework in finance and economic theory exhibits low and predictable inflation rates, appropriate real interest rates, and sustainable and stable fiscal policy. These features are demonstrated by predictable and competitive real exchange rates and viable balance payments. This description of a stable macroeconomic framework goes beyond the stability of macroeconomic factors to include other criterion where macro profile related factors are at levels conducive to growth. During financial crises, measures are taken by authorities, governments and supervisory institutes to bail out the troubled banks, or to support the banking system. These include financial stability packages; emergency liquidity assistances; recapitalization of the capital for the troubled banks; government capital injections; liability guaranties; exchanges rates fixes; international monetary fund programs; macroeconomic adjustment programs; strength supervision channels; government guaranties; interest free rates; foreign currency liquidity to maintain the exchange rates, external liquidity controls; establishment of minimum requirement or new currency regulation for foreign currency rates; structure or restructure reforms for external assistances; foreign exchange intervention and more. 
Therefore, looking back at the behavior of banks during times of financial crises, and bail out methods as a means of evaluating the soundness of banks (European banks) and as a survival mechanism, could give new insight on how to handle new upcoming crises. The influence of macro profile was significantly and vigorously addressed during crises in most of financial reports and outlooks. This paper gives a comprehensive analysis of the journey of European banks past and present and evaluates the most common methodologies used to measure the soundness of European banks during both crises and stable periods. The impact of the macro profile on the soundness of banks is vital, but equally important are considerations on how the determinants of profitability carry the weight of bank soundness. For example, if GDP increases, a bank could earn higher returns by risk-taking policies, which will lead to more profitability. However, taking risk may raise real interest rates which will undermine the bank's stability. In theory, both income and expenditure are likely to be pro-cyclical since profit depends on a bank's expense policy and credit risk profile. Moreover, taking risk can also reflect losses of a bank and minimize profitability.

\section{Objectives of The Study}

The general objective of the theoretical study is to evaluate the impact of Macro profile on the soundness of banks.

1. Determine whether it is plausible to only focus on the interaction between profitability and macroeconomic factors for future examinations of European banks soundness.

\section{Macroeconomic Determinants of Profitability and Bank Soundness - Literature review}

Soundness of banks can be interpreted by the soundness of profitability, if the external determinants are chiefly predictable and the internal factors are controlled by minimum requirements, regulatory and supervisory, so that banks can absorb any crisis that lies on the horizon. In addition, macroeconomic factors such as GDP growth, high and unpredictable inflation, fluctuation of exchange rates, high real interest rates, and rapid credit expansion are associated with bank instability. Early literature (Short, 1979) suggested that macroeconomic factors are unique for each bank, and for each country. There are extensive empirical studies that have examined the impact of GDP on the bank profits (A Demirgüç-Kunt, A., \& Huizinga, 1999; Athanasoglou, P., Delis, M., \& Staikouras, C., 2006; F. Pasiouras, K. Kosmidou, 2007; Anbar, A., \& Alper, D., 2011; Sufian, F., 2011; Claeys and Vennet, 2008; Kosmidou, K., Tanna, S., \& Pasiouras, F., 2005; Combey, A., \& Togbenou, A., 2017). The following scholars assessed the impact of inflation on bank profit, such as Athanasoglou, P., Delis, M., \& Staikouras, C., 2006; Kosmidou, K., 2008; Athanasoglou et al., 2008; TrujilloPonce, 2013; Bourke, 1989; Molyneux and Thornton, 1992; Munteanu, I., 2012; Petria, N., Capraru, B., \& Ihnatov, I., 2015; Combey, A., \& Togbenou, A., 2017 and others.

The first and most repeated external determinant in all examined empirical studies was inflation which causes variations in bank profitability. Its effect depends on the assumption that wages and other non-interest costs will increase faster than the rate of inflation, which is not unusual and, accordingly, the annual growth in the consumer price index in each country was used as an independent variable. Since the maturity of economy forecasts the forthcoming inflation precisely and consequently, banks can manage their operating costs and increase the rates on loans faster than the operating costs to earn higher profits. The inflation and banking performance relationship has been introduced in the theory by Revell (1979) as he demonstrated that inflation affects bank's profitability through salaries and operating costs. Nevertheless, the relationship between the inflation rate and profitability was vague and depended on whether the inflation forecasting was predictable or not (Perry, 1992; Revell, 1979). Higher levels of economic growth will boost the lending operations in banks, and thus increase the margins, and improve the quality of their assets. (Bourke, 1989 and Molyneux and Thornton, 1992) concluded that the relationship between either inflation or long-term interest rate and profitability was positive.

With a fully anticipated inflation rate, bank management can adjust interest rates appropriately to increase revenues faster than costs, which should have a positive impact on profitability (Trujillo-Ponce, 2013; Athanasoglou, P., Delis, M., \& Staikouras, C., 2006). A higher level of income had a positive impact on the demand for deposits and reduced the incentive for banks to set higher deposit interest rates. However, bank managements were unable to adequately forecast future inflation, even though, the monetary policy in the EU countries was usually predictable (Alexiou and Sofoklis, 2009). Thus, higher rates could have been charged on loans, less interest rates being paid on deposits and so on (Goddard, J., Molyneux, P., \& Wilson, J. O. 2004). 
The second most repeated determinate was GDP. The actual rate of annual GDP supports the argument of the association between economic growth and the financial sector performance. In rich countries with advanced banking sectors the effect was smaller. When the ownership of banks was addressed, the impacts of both GDP growth and inflation on bank performance were significant in all cases but with opposite signs for domestic and foreign banks, due to different levels of knowledge of country macroeconomic conditions and expectations concerning inflation rate between domestic and foreign banks (Pasiouras, F., \& Kosmidou, K., 2007; Havrylchyk, O., \& Jurzyk, E. M., 2006; Combey, A., \& Togbenou, A., 2017). Additionally, domestic and foreign banks tend to serve different customer segments that may react differently under the same macroeconomic conditions. On the contrary, an increase in the money market rate, ceteris paribus, makes it more attractive to invest in risk-free securities that represent an alternative to detain deposits; the subsequent reduction in deposits demand determines an upward pressure on the interest rate on deposits (L Gambacorta, 2008).

Poor economic conditions negatively correlated with the quality of the loan portfolio and bank profitability, thus generating credit losses and increasing the provisions of banks. However, with any improvement in economic conditions, the condition of borrowers' solvency and lending effect positively on banks' profitability (Demirguc-Kunt and Huizinga, 1999; Bikker and Hu, 2002; Athanasoglou et al., 2008). Moreover, real GDP growth has a positive impact on banking performance through different channels: competition-stability, risk-taking, net interest income, improvement of loan losses, and operating costs (Berger, A. N., Klapper, L. F., \& Turk-Ariss, R., 2009; Agoraki, M. E. K., Delis, M. D., \& Pasiouras, F., 2011; Jiménez, G., Lopez, J. A., \& Saurina, J., 2013; Bolt, W., De Haan, L., Hoeberichts, M., Van Oordt, M. R., \& Swank, J., 2012; Calza A.\& Sousa J, 2006). Also, higher GDP growth implies higher disposable income, lower unemployment and reduces defaults on consumer loans. Net interest income and loan losses were therefore pro-cyclical with GDP growth. However, the relationship between banks' operating costs and GDP growth was indefinite. Such unfavorable economic conditions (e.g. low GDP growth rates) may decrease deposits, loans and bank management costs while increasing the costs of collecting payments on loans (Bolt, W., De Haan, L., Hoeberichts, M., Van Oordt, M. R., \& Swank, J., 2012).

The real GDP per capita seems to have no significant effect on bank profitability (even though the results strengthen if it's used) since the tight monetary policy of the examined period constrained bank lending. Thus, as soon as price stability was achieved, we should expect a stronger relationship between economic growth and bank profits, through increased lending, improvement in bank asset quality, enhancement of borrowers' access to the South East European markets and a decrease in supervisory toughness as well as uncertainty associated with macroeconomic instability (Athanasoglou, P., Delis, M., \& Staikouras, C., 2006). Few studies suggested that bank profits were correlated with the business cycle as measured by GDP (Demirguc-Kunt and Huizinga, 2000; Bikker and Hu, 2000; Quagliariello, M. 2007). Demirguc-Kunt and Huizinga (1999) stated that in countries where banking assets constitute a larger portion of the GDP, banks had smaller margins and were less profitable. The business cycle's

effect on profitability was positive, only when output was above its trend (Athanasoglou, SN Brissimis, MD Delis, 2008). Moreover, (Demirguc-Kunt \& Huizinga, 2000, Albertazzi, U., \& Gambacorta, L., 2009; Quagliariello, M., 2007; Sufian, F., \& Chong, R. R., 2008, Bolt, W., De Haan, L., Hoeberichts, M., Van Oordt, M. R., \& Swank, J., 2012; Bikker and Hu, 2002) tried to assess the effect of business cycle on banks' profitability. In theory, the combinations of several indicators of financial stability were better suited to indicate the state of bank system stability than individual variables.

Even though the concentration ratio was a banking industry factor, it is always added when addressing the profitability and macroeconomic profile. The concentration ratio measures the degree of banking competition in a national banking sector and it positively affects bank profitability, since larger banks tend to have higher margins. Williams (2003) suggested that concentration ratio may act as a barrier to entry into markets where domestic banks are highly concentrated, implying a negative impact on profits (Chen, S. H., \& Liao, C. C., 2011). One study showed that national market concentration and merger policy were significant, however, parent nation financial development and parent bank profits are additionally relevant (Sturm, J. E., \& Williams, B., 2008), some studies suggested that market share and concentration become explanatory impotence when included in the model (Athanasoglou, P., Delis, M., \& Staikouras, C., 2006; Smirlock, 1985; Evanoff and Fortier, 1988). Moreover, it was significantly negative by Staikouras, C. K., \& Wood, G. E. (2004). 
Finally, it seems that concentration was less beneficial in terms of profitability to the Greek commercial banks than competition (K., Kosmidou, 2008). Money supply growth had no significant impact on profits in countries such as Portugal, Spain, France and Germany (Demirguc- Kunt and Huizinga, 1999; Abreu and Mendes, 2001). According to Maudos and de Guevara (2004), there was a positive relationship between market concentration and profitability, while (Petria, N., Capraru, B., \& Ihnatov, I., 2015) suggested that market concentration diminished bank profitability. In highly concentrated markets, banks tend to collude and therefore earn monopoly profits, thus the lack of competition has a positive effect on bank profitability (Short, 1979; Gilbert, 1984; Molyneux, P., Lloyd-Williams, D. M., \& Thornton, J., 1994).

The effective tax rate reflects the explicit taxes paid by the banks (mostly corporate income taxes). In general, the tax rates vary, and the variation offers an opportunity to see whether the differences in effective tax rates affect the profitability of the banks. Due to higher effective tax rates, banks tend to shift a large fraction of their tax burden onto their depositors, borrowers, and purchasers of fee-generating services. For example, Adler and Dumas (1980) pointed out that bank activities which were exposed to exchange rates had greater asset value volatility, while Chamberlain, S., Howe, J. S., \& Popper, H. (1997) showed that exchange rates had the most direct effect on banks with foreign currency transactions and foreign operations, and even without such activities, exchange rates can affect banks indirectly through their influence on foreign competition, the demand for loans, and other aspects of banking conditions.

Lower exchange rates encourage competitiveness of firms due to the price decline of goods manufactured at home and the increasing demand for foreign products (Luehrman, 1991; Addae, A. A., Nyark-Baasi, M., \& Tetteh, M., 2014; A Combey, A Togbenou, 2017). Thus, loans and deposits increase as well as banks' profits. Nevertheless, a lower exchange rate may also reduce domestic consumer purchasing power, as imported goods become more expensive. This situation may increase loans losses and have negative effects on bank's profitability. This would protect those banks from the full impact of the higher tax burden, but it would not eliminate the impact entirely. Thus, consistent with the results of Demirguc-Kunt and Huizinga (1999) a higher effective tax rate had a negative impact on bank profitability. Ukrainian banks profited from exchange rate depreciation despite of low profit. However, it showed variations in bank profitability among domestic banks and banks with foreign capital. Low exchange rate had a positive significant effect on income, and profit on foreign exchange transactions by anticipating exchange rate fluctuations (Davydenko, A. 2010).

According to previous studies, there was a positive relationship between interest rates and banks performance, bank profits increase with higher interest rates that reflected positively on profitability of banks. This was because interest rate directly affected bank interest income and expenses profitability (Ally, Z., 2014). The effect of interest rates and banking market structure on bank profitability was examined by Perry (1992) and Trujillo-Ponce (2013). The interest rate on loans depended completely on real GDP and inflation. Although, real GDP and inflation have a negative impact on the interest rate on deposits, and thus boosts loan demand and increases the interest rate on loans. Lending operations will be encouraged due to the higher rate of money market caused by the opportunity cost of other forms of financing. (Bourke, 1989 and Molyneux and Thornton, 1992) noted a positive relationship between inflation, profitability and the association between long-term interest rates and profitability. High real interest rates were connected to higher interest margins and profitability. For example, developed countries have higher real interest rates and higher interest margins, because demand deposits often pay zero or below-market interest rates. Nevertheless, even very small reductions in banks' lending rates or increases in their borrowing rates may, in aggregate, resulted in substantial redistribution of income to bank customers. Inflation involves higher costs - more transactions and generally more extensive branch networks and higher income from bank float.

Market growth was not suggested extensively in the literature. However, Short (1979) found that asset growth in individual banks was not significant. It was suggested that growth in total market may be considered as a potential variable in the sense that an expanding market, particularly if associated with entry barriers, should produce the capability of earning increased profits. Accordingly, annual growth in money supply in each country was suggested as an independent variable. The significantly negative impact of ratio stock market capitalization to total assets of the deposit money banks to bank's performance was also consistent with the results of Demirguc-Kunt and Huizinga (1999). In other words, the stock market development offered substitution possibilities to potential borrowers, which consequently decreased banks' profits.

The improvement in the regulatory framework, the observed significant credit expansion and the gradual adoption of sound macroeconomic policies, have all positively contributed to competition. While competition 
Financial Markets, Institutions and Risks, Volume 3, Issue 3, 2019 ISSN (online) - 2521-1242 ISSN (print) - 2521-1250

could lower financial intermediation costs and contribute to an improvement in economic efficiency, it could reduce market power and the profitability of banks. Thus, it appears that reform, at this stage of financial system sophistication, caused banks to offer increasingly competitive margins on loans and deposits, which in turn lowers profitability (Athanasoglou, P., Delis, M., \& Staikouras, C., 2006). Moreover, De Guevara, J. F., \& Maudos, J., 2004) emphasized that regardless of deregulation and higher level of concentration, imperfect competition among banks was associated with welfare loss, however, the market power increased during the 1990s in most of EU countries.

The Efficient-Structure and Structure Conduct Performance hypotheses assessed the banks' performance and profitability (Sathye, S., \& Sathye, M., 2004; Doyran, M. A., 2012) and evaluated a bank's profitability in all markets, the lack of potential rivalry empowers all market participations to gain more profits (Evanoff, Douglas D\& D.L. Fortier, 1988). The Efficient Structure hypothesis suggested that by increasing managerial and scale efficiency led to higher concentration, thus higher profits. The Structure Conduct Performance model indicated the relationship between market power and bank profitability (Pasiouras and Kosmidou, 2007) since banking market concentration increased market power by gaining monopoly profits. In addition, the Structure Conduct-Performance hypothesis stated that the higher profits were due to superior management and increased market share (especially in the case of small-to-medium-sized banks). However, the empirical results of Papadopoulos, S. (2004) did not provide any support for the two efficient structure hypotheses. The cost advantages associated with greater bank size. For both hypotheses, deep analysis of the European banks will be needed to determine the impact on bank soundness and profitability.

Finally, similar results were seen when Berger and Humphrey (1997) highlighted that the importance of cost efficiency hypothesis compared to the market-power theory in explaining bank profitability when frontier efficiency analysis was applied. However, the Efficient-Structure theory explains the positive relationship between concentration and profitability as an indirect consequence of efficiency. The Efficient-Structure theory argues that the better managed banks or those with more efficient (and thus more profitable) cost structures could see their market shares increase, thus a higher degree of concentration. Moreover, their study addressed the government merger policy during crises due to the surmise that cost efficiency benefits from mergers policy. Huang, T. H., Chiang, D. L., \& Lin, C. L. (2018) support that merger policy raises the market power and improve economies. However, there was no single pattern of mergers policies could dominate the different patterns of the methods of the mergers. Both the Structure-Conduct-Performance and Market-Power hypotheses were benefited and motivated by greater market power. The Industry concentration factor reflected two theories to explain how the degree of sector concentration affects bank profitability (Athanasoglou, M Delis, C Staikouras - 2006; Molyneux, P., \& Forbes, W., 1995). Additionally, the real GDP growth rate had a positive impact on bank's performance according to the well-documented literature on the association between economic growth and financial sector performance (F Pasiouras, K Kosmidou, 2007).

Nahidah Naser (A Comprehensive Analysis of European Banking Soundness- Theoretical Study, 2019) stated that regardless of the methodology applied to examine the soundness of banks. The external factors increased the prediction of bank soundness, however, in some literature, the change was considered insignificant. It was also noticed that the Moody's structure for forecasting banks' failures and credit profiles accurately employed the macro profile qualitative approach. The macroprudential policies were set to prevent any future financial crisis, while the microprudential policies were set to prevent Banks's failure and idiosyncratic shocks. The hypothetical adverse macroeconomic and financial market scenarios examine the systemic risk by introducing new regulatory and prudential tools. However, Macro stress testing proved unsuccessful to capture the riskier banks inside financial system and underestimated banks' loan and credit losses. For further investigation, I would like to employ forecasting tree regression models and survival analysis to divide banks into different categories to predict distress banks through qualitative and quantitative approaches to forecast and estimate the soundness of banks while emphasizing the role of the most repeated predictable and unpredictable indicators.

Table 1: The Most repeated Macroeconomic Determinants in literature (see Appendix A)

\begin{tabular}{|l|c|c|}
\hline Determinants & Definitions & Frequency \\
\hline Inflation & CPI annual inflation rate & 29 \\
\hline Concentration (Bank specific factor) & Sum of the squared market shares of each bank assets & \\
\hline GDP growth & Real GDP, annual growth rate & 20 \\
\hline Interest rate & One-year real reference interest rate on loans & 20 \\
\hline
\end{tabular}




\begin{tabular}{|c|c|c|}
\hline GDP per Capita & Ratio of GDP to population & 4 \\
\hline Stock Market Ratio & $\begin{array}{l}\text { The ratio of stock market capitalization to total assets of the } \\
\text { deposit money banks }\end{array}$ & 7 \\
\hline Exchange rate & The price of one currency in terms of another currency & 2 \\
\hline Effective tax rate & Total taxes over pretax profit $(\%)$ & 2 \\
\hline Market Growth & Annual Growth in the Market & 2 \\
\hline Market Share & $\%$ of a market (defined in terms of assets) & 1 \\
\hline
\end{tabular}

Source: Own study.

The next figures highlight the journey of Macroeconomic factors in European countries and their impacts during the crises period.

\section{Exchange Rates}
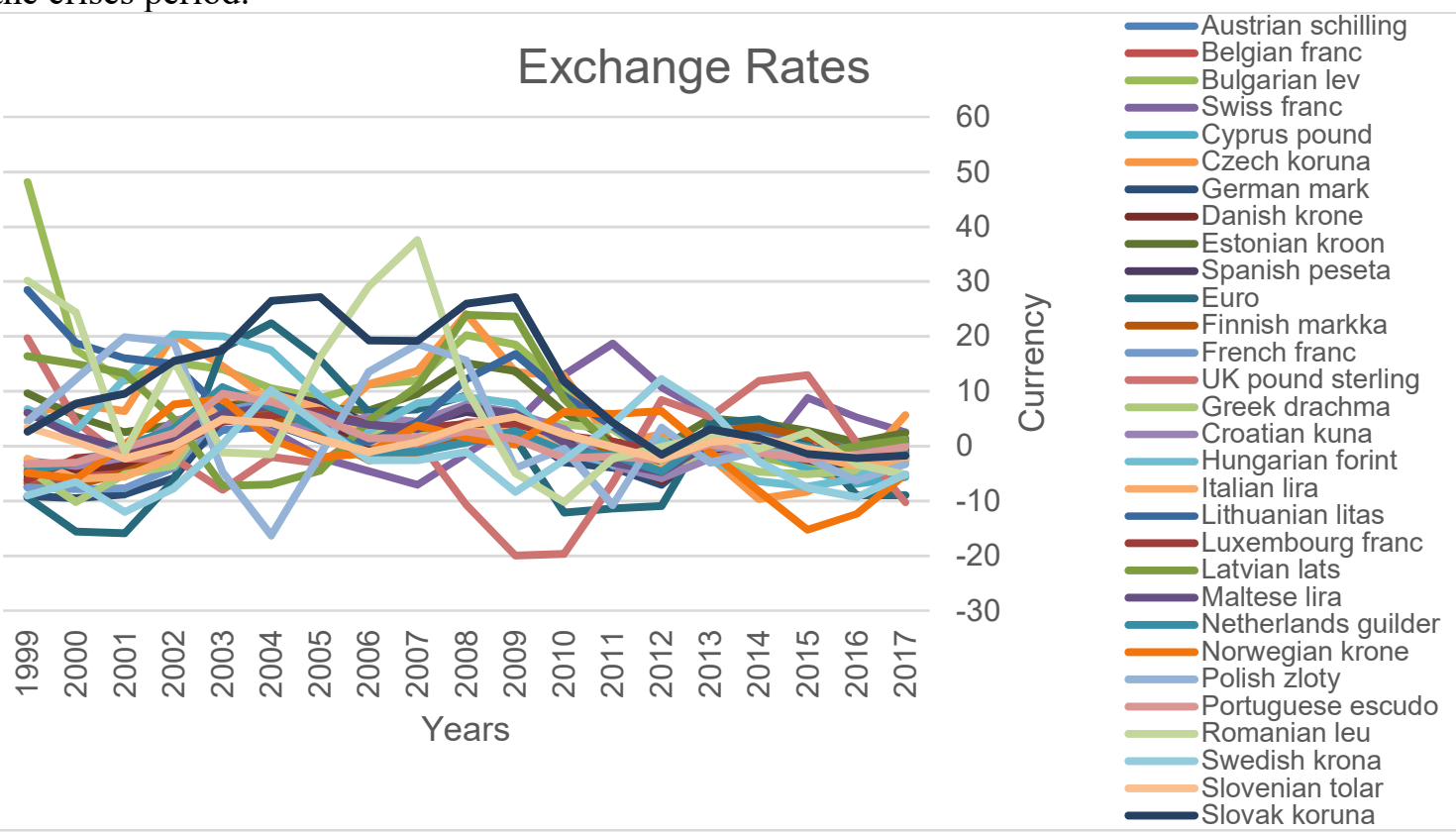

Figure 1: Exchange Rates from 1999 - 2017: Data Resource. European Central Bank- Consolidated Banking data [2]. All banking groups / stand-alone banks irrespective of their accounting / supervisory reporting framework)

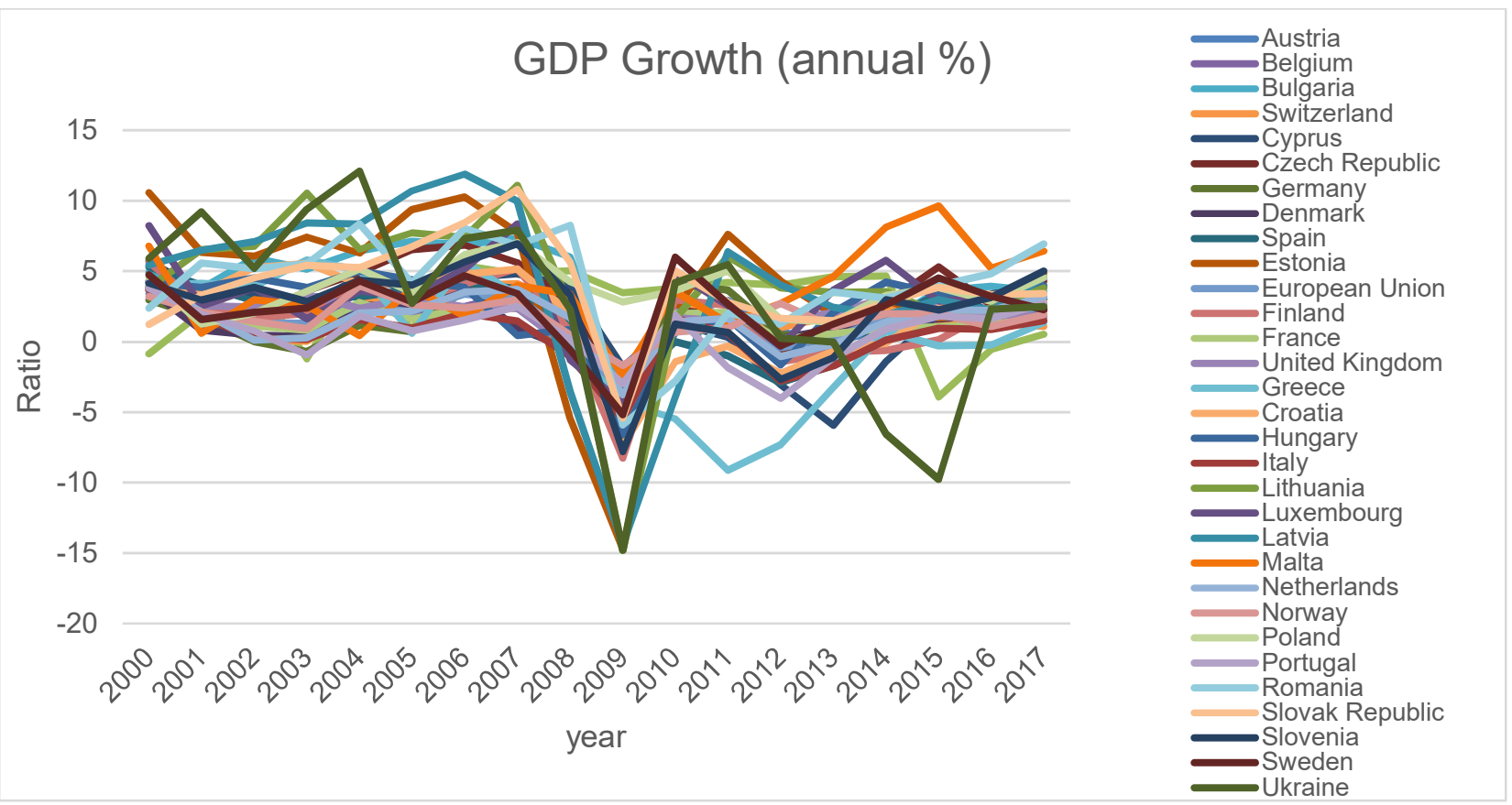

Figure 2: GDP Growth from 2000-2017: Data Resource. European Central Bank- Consolidated Banking data Full sample (All banking groups / stand-alone banks irrespective of their accounting / supervisory reporting framework). 


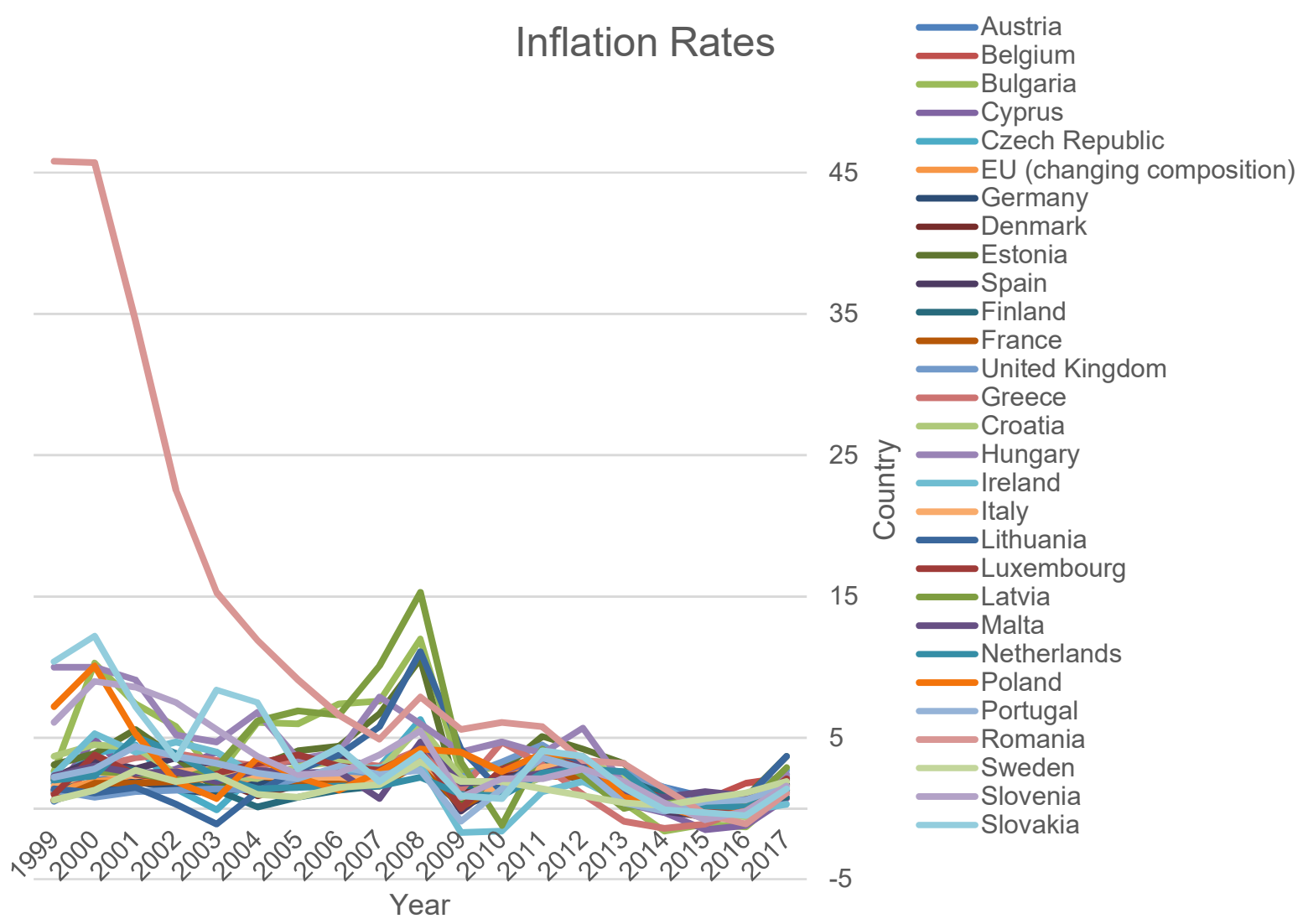

Figure 3: Inflation Rates from 1999-2017: Data Resource. European Central Bank- Consolidated Banking data. Full sample (All banking groups / stand-alone banks irrespective of their accounting / supervisory reporting framework)

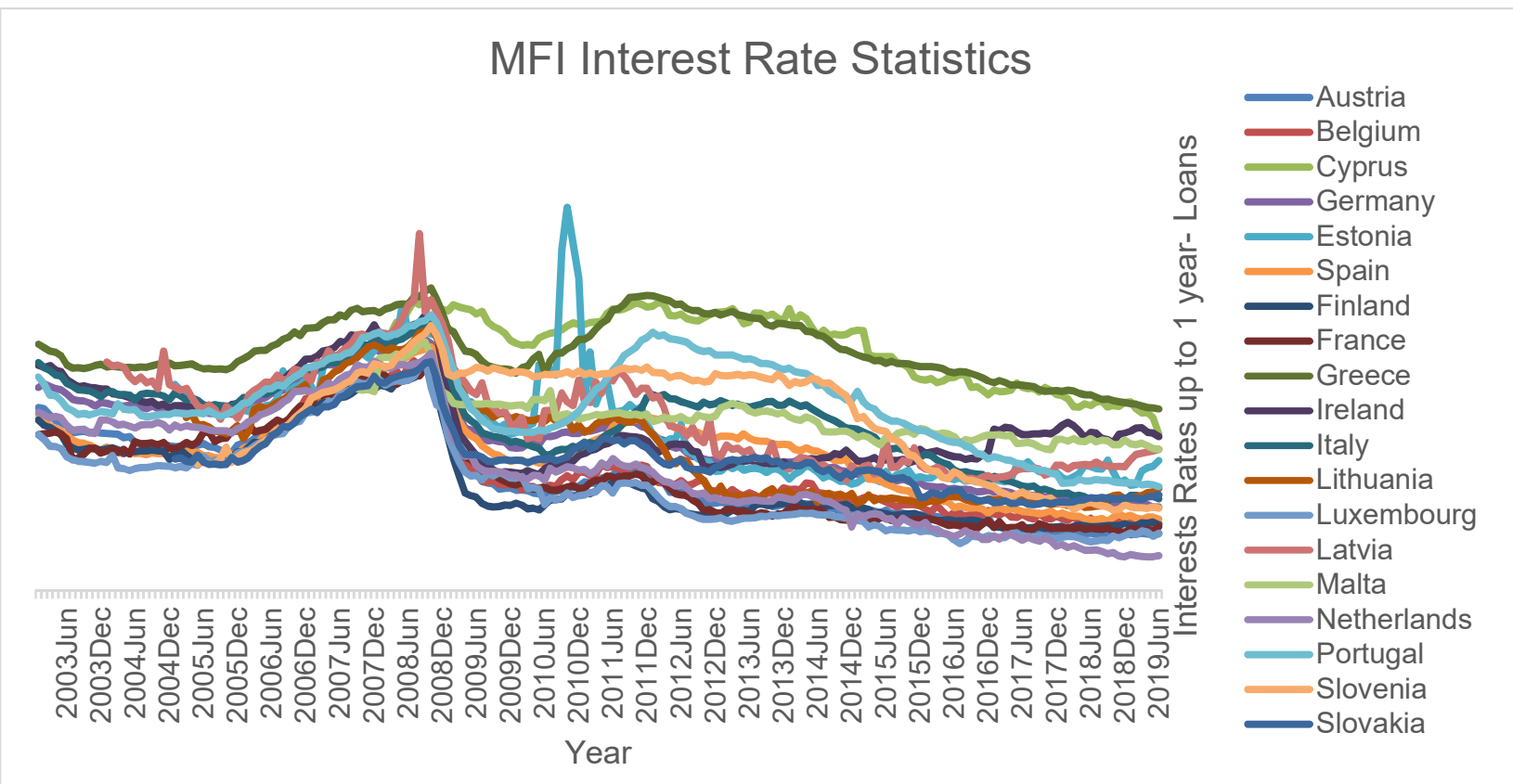

Figure 4: MFI Interest Rate Statistics 2003-2019. Data Resource: European Central Bank, Financial markets and interest rates- Loans. Oesterreichische Nationalbank) 


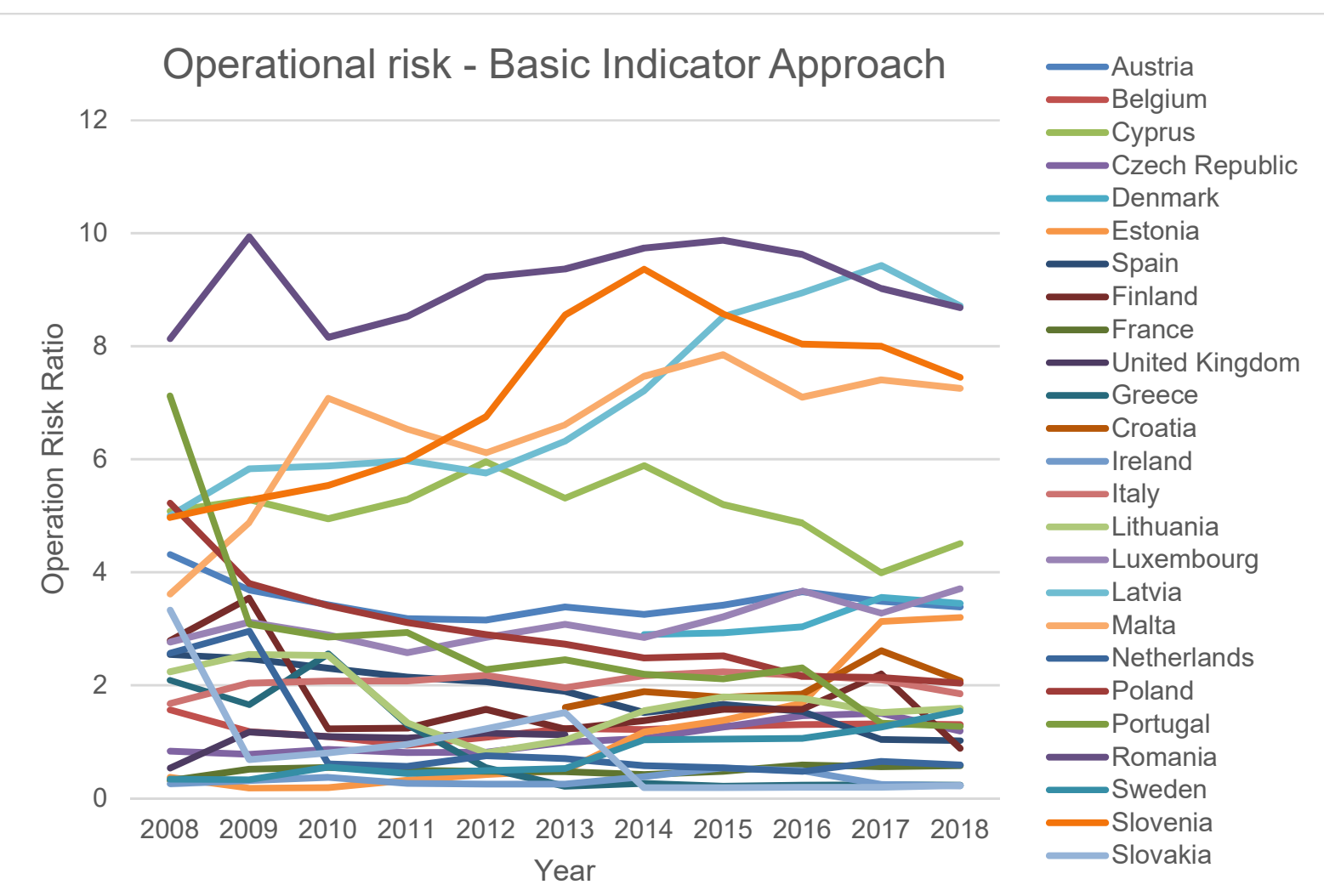

Figure 5: Operational risk - basic indicator approach 2008-2018. Data Resource: European Central Bank, Consolidated Banking data. All banking groups / stand-alone banks irrespective of their accounting / supervisory reporting framework

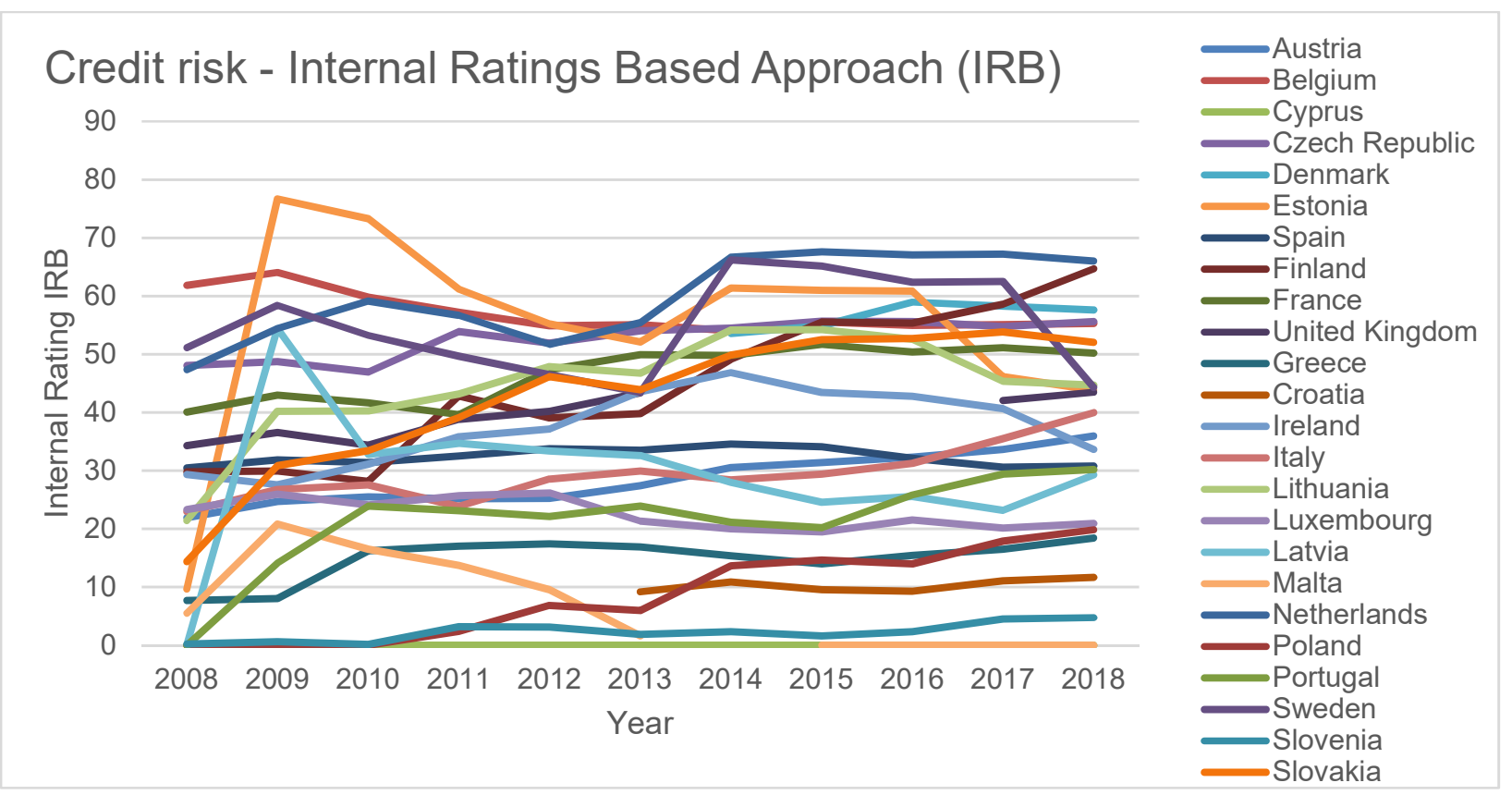

Figure 6: Credit risk - internal ratings-based approach (IRB) from 2008-2018. Data Resource e: European Central Bank Consolidated Banking data. (All banking groups / stand-alone banks irrespective of their accounting / supervisory reporting framework) 


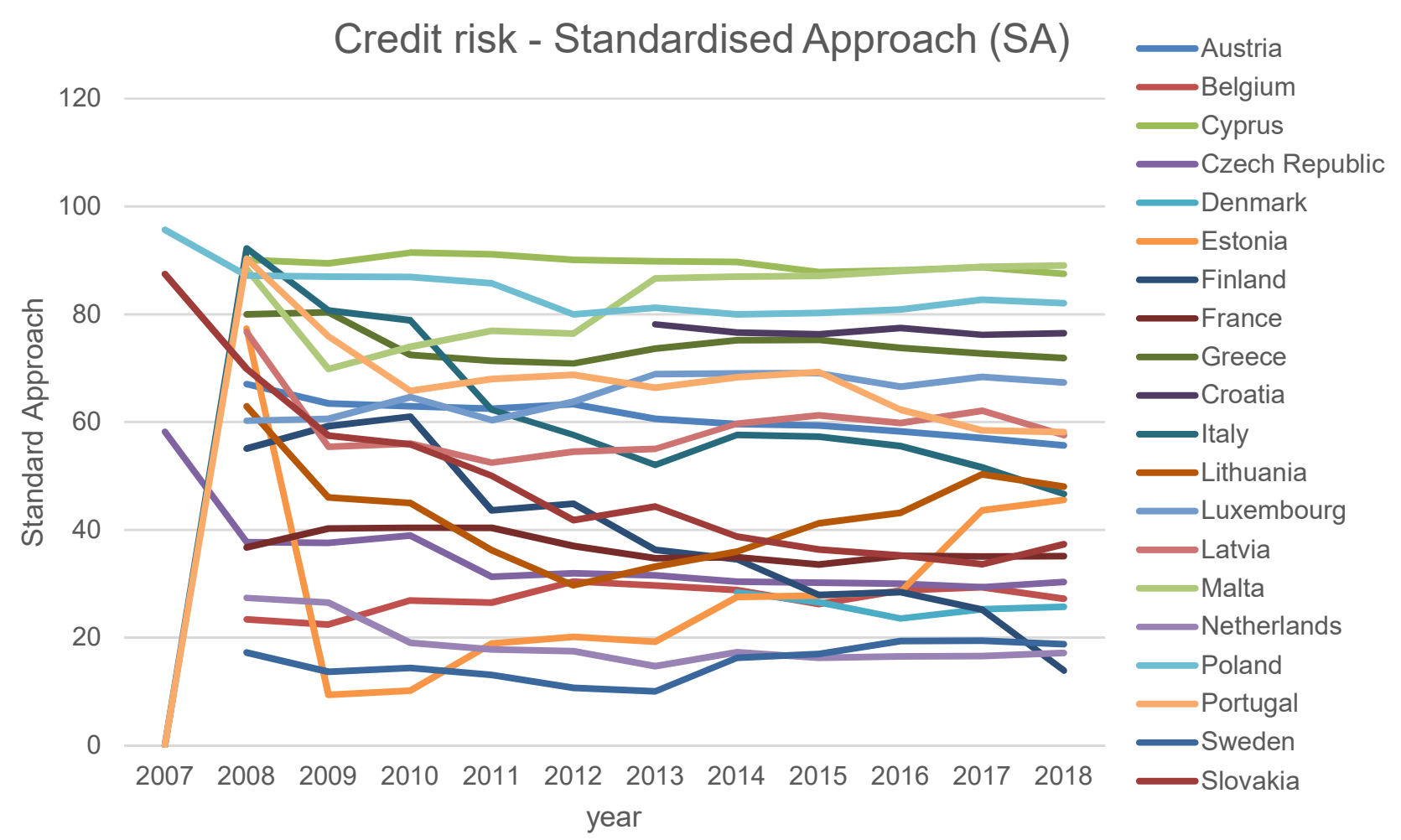

Figure 7: Credit risk - Standard Approach (IRB) from 2007-2018. Data Resource: European Central Bank Consolidated Banking data. All banking groups / stand-alone banks irrespective of their accounting / supervisory reporting framework)
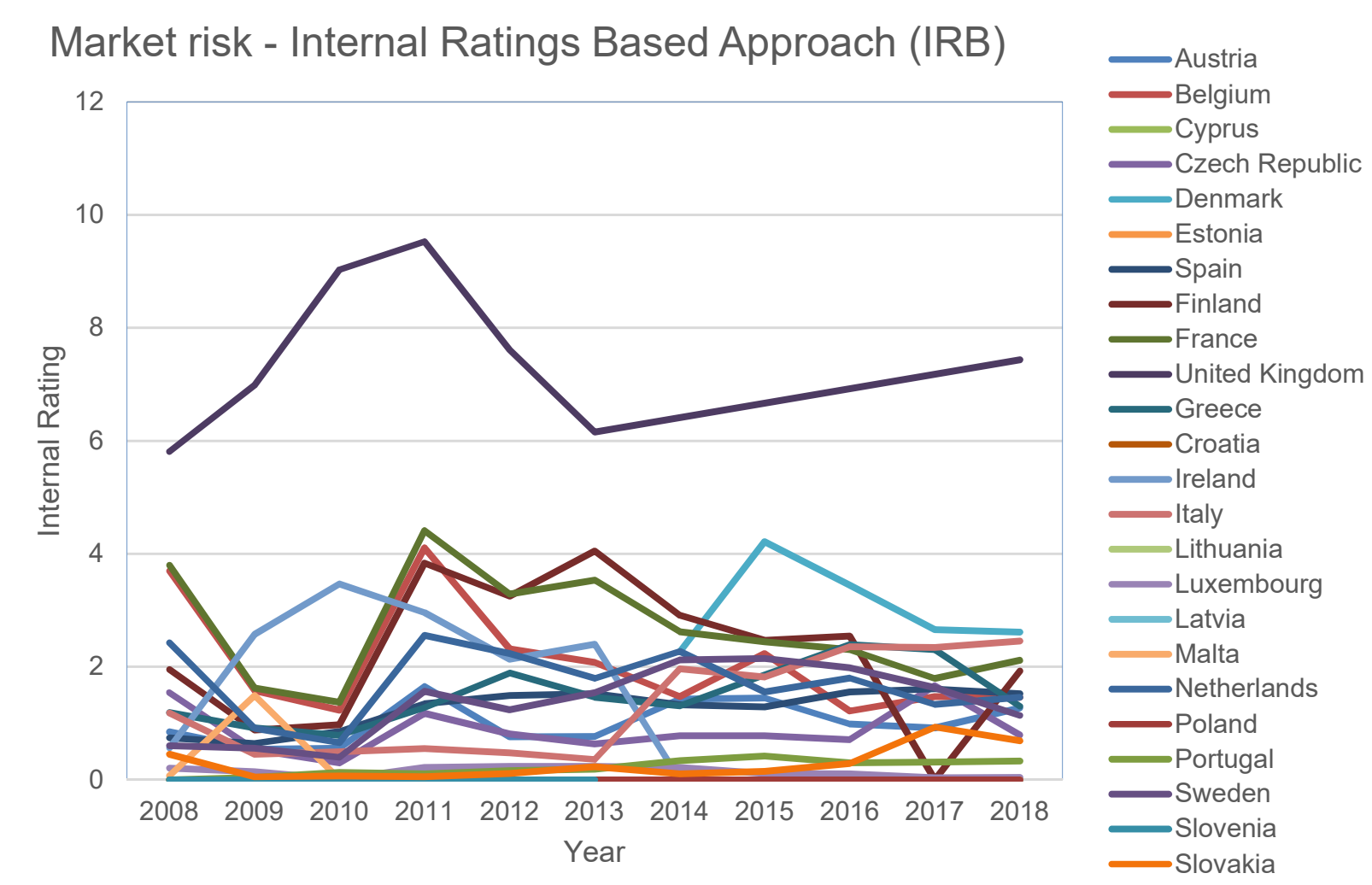

Figure 8: Market risk - Internal Ratings-Based Approach (IRB) from 2008-2018. Data Resource: European Central Bank Consolidated Banking data. 


\section{In depth analysis on past and present European Banks soundness}

The most important macroeconomics indicators of banking crises are related to deposits, capital, and foreign liabilities of bank. Typically, they represent the indirect indicators, of changes in the liquidity risk, credit risk and exchange rate risk, respectively. In other words, any fluctuations in these indicators indicate changes in the fragility of selected banks. This part is dedicated to analyses of the type of crises that European banks faced in the past and present, descriptions of the crises and measures / polices that were taken by governments and authorities (data collection was from European Central Bank [9]). The macro profile was heavily addressed during these crises.

Table 2: The History of European Banks based on. Resource: European Central Bank/Euro System ${ }^{\mathrm{i}}$

\begin{tabular}{|c|c|c|c|}
\hline Country & Type of crisis & Brief description of the crisis & Crisis management and policies \\
\hline Austria & $\begin{array}{l}\text { The crisis was due to high credit } \\
\text { growth and leverage, afterward } \\
\text { bank sector suffered misaligned } \\
\text { incentives, low capitalization } \\
\text { and profitability, mismatches } \\
\text { and market illiquidity, exposure } \\
\text { concentration. The liquidity } \\
\text { problem was trigged by Lehman } \\
\text { Brothers' default (2007-2016). }\end{array}$ & $\begin{array}{l}\text { The US subprime market hit the } \\
\text { Austrian banking sector } \\
\text { directly but was limited, and } \\
\text { caused by dry-up of the } \\
\text { interbank markets due to } \\
\text { defaulting Lehman Brothers, as } \\
\text { a consequence the long-term } \\
\text { structure of the banking sector } \\
\text { was weaker, and credit spreads } \\
\text { raised in CESEE (Central, } \\
\text { Eastern and Southeastern } \\
\text { Europe) in early 2009. the } \\
\text { downturn, the NPLs grew in } \\
\text { 2009. In spite of international } \\
\text { investors fears, the situation } \\
\text { stabilized in a short time due to } \\
\text { the Vienna Initiative. }\end{array}$ & $\begin{array}{l}\text { Introducing a financial Market Stability } \\
\text { Package to support Capital by the } \\
\text { federal state of Austria in 2008, as well } \\
\text { as funding guarantees and managing } \\
\text { the public participations in the banking } \\
\text { system using Interbank Market Support } \\
\text { Act and the Financial Market Stability } \\
\text { Act. Introducing "soft law" and the } \\
\text { new recommendations to cut the } \\
\text { lending in foreign currency. The new } \\
\text { Minimum Standards issued by the } \\
\text { FMA in 2013 were taken into } \\
\text { consideration as well as the ESRB's } \\
\text { recommendations and supervisory } \\
\text { experience to manage the lending in } \\
\text { foreign currency by subsidiaries of } \\
\text { Austrian banks abroad (especially in } \\
\text { CESEE). } \\
\text { Cross-border collaboration by FMA } \\
\text { and OeNB was launched in January } \\
\text { 2009. Applied OeNB and the FMA } \\
\text { supervisory guidance to strengthen the } \\
\text { sustainability of the business models of } \\
\text { large internationally Financial stability } \\
\text { in Austria and host countries. Most } \\
\text { domestic banks' business in the region } \\
\text { followed the OeNB and the FMA Guide } \\
\text { Principles in } 2010 \text {. Requesting higher } \\
\text { bank capital for the medium and long } \\
\text { term, more balanced refinancing } \\
\text { structure of exposed subsidiaries to } \\
\text { absorb potential crisis situations. Three } \\
\text { Austrian banking groups had applied } \\
\text { the guidance; Erste Group Bank, } \\
\text { Raiffeisen Zentralbank and UniCredit } \\
\text { Bank Austria from } 2012 \text { to } 2015 \text {. Later, } \\
\text { only Erste Group Bank and Raiffeisen } \\
\text { Bank International applied the } \\
\text { guidance. }\end{array}$ \\
\hline Belgium & $\begin{array}{l}\text { Leverage and credit growth, } \\
\text { excessive mismatches and } \\
\text { market illiquidity, exposure } \\
\text { concentration, misaligned } \\
\text { incentives (2007-2012). }\end{array}$ & $\begin{array}{l}\text { The Belgian financial sector } \\
\text { was deeply affected by Lehman } \\
\text { Brothers' default. A severe } \\
\text { disruption in the wholesale } \\
\text { financing } \\
\text { vulnerability of individual } \\
\text { institutions and strong } \\
\text { deleveraging to reduce the debt } \\
\text { to increase the profitability and } \\
\text { liquidity in most credit } \\
\text { institutions and insurance } \\
\text { companies. }\end{array}$ & $\begin{array}{l}\text { Government interventions to restore the } \\
\text { stability and confidence in the financial } \\
\text { markets, such as re-capitalizations, } \\
\text { asset/liability guarantees, emergency } \\
\text { liquidity assistance and an increased } \\
\text { amount of deposit guarantees. The } \\
\text { state support played a huge role of } \\
\text { solving the crisis. }\end{array}$ \\
\hline Bulgaria & 1995-1997 & $\begin{array}{l}\text { The crisis was trigged during } \\
\text { the transition process in the } 90 \mathrm{~s} \\
\text { and caused deficiencies in the } \\
\text { banking sector and the }\end{array}$ & $\begin{array}{l}\text { In July 1997, introducing new } \\
\text { measurements, such as tightening the } \\
\text { fiscal discipline and currency board } \\
\text { arrangement to overcome the crisis. }\end{array}$ \\
\hline
\end{tabular}




\begin{tabular}{|c|c|c|c|}
\hline & & $\begin{array}{l}\text { regulatory framework, } \\
\text { hindered by the structural } \\
\text { reforms in the economy, losses } \\
\text { in the state budget and banks, } \\
\text { poor fiscal discipline, } \\
\text { unbounded monetization of } \\
\text { fiscal deficits, inefficient } \\
\text { unrestricted monetary policy } \\
\text { and loss of confidence in the } \\
\text { domestic banks. }\end{array}$ & $\begin{array}{l}\text { The principles of the currency board in } \\
\text { Bulgaria were based on fixing the } \\
\text { exchange rate of the national currency } \\
\text { against the euro, full coverage of the } \\
\text { central bank monetary liabilities, the } \\
\text { central bank was obligated to sell and } \\
\text { purchase levs against euro at a fixed } \\
\text { exchange rate, central bank } \\
\text { recommended no open market } \\
\text { operations as well as no extended } \\
\text { credits and guarantees to the } \\
\text { government. The central bank provided } \\
\text { credits only to the banks with } \\
\text { liquidation risk that threatened the } \\
\text { stability of the banking system. }\end{array}$ \\
\hline Cyprus & $\begin{array}{l}\text { Stock market bubble during the } \\
1990 \text { s }\end{array}$ & $\begin{array}{l}\text { The burst of the stock market } \\
\text { bubble was due to joining the } \\
\text { EU in 2000, and other positive } \\
\text { political and economic } \\
\text { developments. Both investors } \\
\text { and consumers suffered major } \\
\text { losses due to the crash in share } \\
\text { prices; loss of confidence in } \\
\text { market, some trading account } \\
\text { debts were written off by banks } \\
\text { and investment firms which } \\
\text { spurred customers to buy } \\
\text { shares. }\end{array}$ & Nothing to report. \\
\hline & $\begin{array}{l}\text { The Cypriot banking sector } \\
\text { showed leverage, excessive } \\
\text { credit growth, exposure } \\
\text { concentration, mismatches and } \\
\text { market illiquidity, misaligned } \\
\text { incentives (2011-2016). }\end{array}$ & $\begin{array}{l}\text { Cypriot economic growth and } \\
\text { ambitions to become a leading } \\
\text { international provider of } \\
\text { banking services trigged the } \\
\text { crisis by attracting significant } \\
\text { inflows of foreign deposits in } \\
\text { the banking system and } \\
\text { imposing higher interest rates } \\
\text { on deposits. Consequently, a } \\
\text { dramatic expansion of banks' } \\
\text { balance sheets, both } \\
\text { domestically and abroad } \\
\text { transferred as imbalances and } \\
\text { vulnerabilities in the banking } \\
\text { sector. The rapid expansion of } \\
\text { domestic credit was due to } \\
\text { significant inflows of foreign } \\
\text { deposits and banks imprudent } \\
\text { lending practices, inadequate } \\
\text { risk management and corporate } \\
\text { governance frameworks } \\
\text { escalated the real estate boom. } \\
\text { Fast acceleration of bank loans } \\
\text { accompanied by growth of debt } \\
\text { for both households and non- } \\
\text { financial corporations and } \\
\text { increased the vulnerability to } \\
\text { absorb shocks. High lending } \\
\text { rate exercises in banking sector } \\
\text { deteriorated the financial } \\
\text { position and their ability to } \\
\text { meet their debt obligations. } \\
\text { There was a rapid increase in } \\
\text { non-performing loans, } \\
\text { catastrophic losses during debt } \\
\text { restructuring of Greek } \\
\text { Government and the Private } \\
\text { Sector Involvement. The } \\
\text { solvency of the Cypriot }\end{array}$ & $\begin{array}{l}\text { Due to the lower rating of Cyprus } \\
\text { banks, the liquidity buffers were } \\
\text { gradually worn away, and banks were } \\
\text { unable to raise liquidity through the } \\
\text { refinancing operations of the } \\
\text { Eurosystem, thus the Central Bank of } \\
\text { Cyprus provided Emergency Liquidity } \\
\text { Assistance to cover banks' liquidity } \\
\text { needs. Downsizing of the credit } \\
\text { institution sector was needed given its } \\
\text { large size and the accumulated } \\
\text { imbalances by the carve-out of the } \\
\text { Greek operations of Bank of Cyprus, } \\
\text { Cyprus Popular Bank and Hellenic } \\
\text { Bank pursuant to the provisions of The } \\
\text { Resolution of Credit as well as other } \\
\text { Institutions Law of } 2013 \text {. Also, capital } \\
\text { restrictions were imposed on banks, } \\
\text { thus decreasing liquid assets in the } \\
\text { Greek and Cyprus sovereign bonds. } \\
\text { Then, customer deposits were } \\
\text { downgraded and a decline in cash } \\
\text { inflows from loan repayments } \\
\text { followed, since the proportion of } \\
\text { customers that did not meet the } \\
\text { specified repayment schedule of their } \\
\text { debt obligations increased. } \\
\text { State-aid supported the Cyprus Popular } \\
\text { Bank (CPB) by recapitalizing the bank } \\
\text { as a loan. The remaining assets of the } \\
\text { bank, including foreign subsidiaries } \\
\text { and branches were liquidity injected to } \\
\text { compensate uninsured depositors, other } \\
\text { creditors, while shareholders of the } \\
\text { bank remained in the legacy part of } \\
\text { CPB. BoC was recapitalized by the } \\
\text { bail-in of shareholders, bondholders.the } \\
\text { European Financial Stability Facility / } \\
\text { European Stability Mechanism and the }\end{array}$ \\
\hline
\end{tabular}




\begin{tabular}{|c|c|c|c|}
\hline & & $\begin{array}{l}\text { banking sector and the quality } \\
\text { of banks' loan portfolio } \\
\text { deteriorate sharply in mid-2011 } \\
\text { amid the unfavorable } \\
\text { macroeconomic environment } \\
\text { in Cyprus and Greece. More } \\
\text { specifically, the three largest } \\
\text { domestic banks suffered total } \\
\text { losses due to the 'haircut' of the } \\
\text { Greek Government Bonds } \\
\text { (GGBs). The banking sector } \\
\text { suffered accumulating current } \\
\text { account deficits, significant } \\
\text { losses in competitiveness, } \\
\text { growing budget deficits and } \\
\text { inflating public debt. }\end{array}$ & $\begin{array}{l}\text { International Monetary Fund in mid- } \\
2012 \text { to recover the economy and to } \\
\text { ensure conditions of financial stability. } \\
\text { A Cyprus macroeconomic adjustment } \\
\text { program was reached at the end of } \\
\text { March } 2013 \text {. The key objectives were } \\
\text { to restore the soundness of the Cypriot } \\
\text { credit institutions sector, rebuild } \\
\text { depositors' and market confidence by } \\
\text { thoroughly restructuring, strengthening } \\
\text { the supervision role and curtailing } \\
\text { financial institutions, as stated in the } \\
\text { terms of the Eurogroup agreement in } 25 \\
\text { March } 2013 \text {. }\end{array}$ \\
\hline Czech & $\begin{array}{l}\text { The Czech banking sector had } \\
\text { leverage and rapid credit growth } \\
\text { as early signs of crisis, along } \\
\text { with misaligned incentives and } \\
\text { infrastructure resilience. Debt- } \\
\text { financed privatization of the } \\
\text { enterprise sector and capital } \\
\text { inflows in a regime of fixed } \\
\text { exchange rate escalated the } \\
\text { crisis, resulting in credit growth } \\
\text { and severe external imbalances. } \\
\text { Misaligned incentives caused by } \\
\text { an institutional setting and a } \\
\text { moral hazard escalated the credit } \\
\text { growth and contributed to bank } \\
\text { problems after the currency } \\
\text { crisis ended. The bank crisis was } \\
\text { also escalated by the } \\
\text { privatization process of the } \\
\text { enterprise sector in which } \\
\text { numerous legacy assets were } \\
\text { transferred from communist } \\
\text { regime to corporations (1997- } \\
\text { 2000). }\end{array}$ & $\begin{array}{l}\text { In the 1990s, the external } \\
\text { imbalances were caused by } \\
\text { overheating economics. } \\
\text { Several measures were applied, } \\
\text { such as increasing the interest } \\
\text { rates and stabilization } \\
\text { packages. During that time, } \\
\text { strong capital inflows and fixed } \\
\text { exchange rates occurred. In } \\
\text { 1998, the need to stabilize the } \\
\text { banking sector by providing } \\
\text { guarantees for legacy assets } \\
\text { accelerated the problem. } \\
\text { Finally, one of the systemic } \\
\text { banks had to merge with } \\
\text { another systemic bank after } \\
\text { defaulting. }\end{array}$ & $\begin{array}{l}\text { The first stabilization package was } \\
\text { introduced in April 1997, the second } \\
\text { stabilization package in the mid of } 1997 \\
\text { through different channels: fiscal } \\
\text { tightening: wage freezes; import } \\
\text { deposits; legal and institutional } \\
\text { reforms. In May 1997, FX intervention } \\
\text { (a conventional monetary policy tool) } \\
\text { was employed by the central bank. } \\
\text { Around mid-1997, the exchange rate } \\
\text { regime was changed to manage floating } \\
\text { of currency. Institutional consolidation } \\
\text { from } 1991-2007 \text { provided guarantees } \\
\text { for banks with bad assets. }\end{array}$ \\
\hline \multirow[t]{2}{*}{ Germany } & $\begin{array}{l}\text { The crisis was due to the failing } \\
\text { of Herstatt bank 1973. Prior to } \\
1974 \text {, there was increasing } \\
\text { leverage in real estate } \\
\text { construction and an inflationary } \\
\text { environment that led to } \\
\text { misjudgment of the } \\
\text { creditworthiness of borrowers } \\
\text { and misallocation of capital in } \\
\text { banks. The banking sector was } \\
\text { vulnerable to a systemic banking } \\
\text { crisis aka a "credit crunch" due } \\
\text { to the implementation of } \\
\text { counter-cyclical and/or real } \\
\text { estate related macro-prudential } \\
\text { instruments. In March 1973, the } \\
\text { tightness of liquidity regulation } \\
\text { (counter-cyclically), revoking an } \\
\text { easing of those standards in } \\
\text { 1969. }\end{array}$ & $\begin{array}{l}\text { During 1970s, the floating } \\
\text { exchanges rates reassured new } \\
\text { trade opportunities, while } \\
\text { inappropriate risk management } \\
\text { in banks occurred. In June } \\
\text { 1974, the closure of the } \\
\text { insolvent Herstatt bank caused } \\
\text { a disruption in the settlement of } \\
\text { a large number of foreign } \\
\text { exchange payments. } \\
\text { Internationally, the loss of } \\
\text { confidence in the banking } \\
\text { sector due to bank's failure and } \\
\text { fragility (Euro-currency } \\
\text { market) after a boom period. } \\
\text { Domestically, a number of } \\
\text { smaller and mid-sized private } \\
\text { banks suffered deposits } \\
\text { outflows due to a fragile } \\
\text { economic environment caused } \\
\text { by oil-price shock, high } \\
\text { inflation, and weak industrial } \\
\text { investment and slowing } \\
\text { residential construction. }\end{array}$ & $\begin{array}{l}\text { The Bundesbank managed to restore } \\
\text { the whole rediscount quotas and offered } \\
\text { unlimited Lombard credit at standard } \\
\text { rate. Refinancing private and regional } \\
\text { banks improved, as well as the } \\
\text { reconstruction Loan Corporation } \\
\text { (KFW) bolstered the lending process to } \\
\text { small firms. The Bundesbank } \\
\text { participated in the establishment of a } \\
\text { liquidity consortium bank to support } \\
\text { banks that were facing temporary } \\
\text { difficulties. The incomplete deposit } \\
\text { insurance scheme was reformed. } \\
\text { Regulations regarding banks' foreign } \\
\text { exchange transactions and tighter } \\
\text { capital ratios reduced the likelihood of } \\
\text { any similar events in the future. } \\
\text { International interbank assets and } \\
\text { liabilities suffered a sharp decline. In } \\
\text { December 1974, the BIS's Committee } \\
\text { on Banking Regulations and } \\
\text { Supervisory Practices. }\end{array}$ \\
\hline & $\begin{array}{llr}\text { The early } & 2000 \mathrm{~s} & \text { crisis was } \\
\text { driven } & \text { by: } & \text { exposure } \\
\text { concentration, } & \text { without violation }\end{array}$ & $\begin{array}{l}\text { Banks adjusted their balance } \\
\text { sheets and corrected the } \\
\text { lending standards in a pro- }\end{array}$ & $\begin{array}{l}\text { The most distressed banks had to } \\
\text { stabilize or merge within their } \\
\text { respective banking groups. The }\end{array}$ \\
\hline
\end{tabular}




\begin{tabular}{|c|c|c|c|}
\hline & $\begin{array}{l}\text { of standard large exposure } \\
\text { regulations, accumulated credit } \\
\text { and stock market valuations } \\
\text { were written off; leverage and } \\
\text { excessive credit growth } \\
\text { appeared in balance sheets of } \\
\text { non-financial borrowers and } \\
\text { banks, where leverage increased } \\
\text { the risk of pro-cyclical behavior } \\
\text { in the downturn; misaligned } \\
\text { incentives: conflicts of interests } \\
\text { between financial advisors / } \\
\text { brokers / stock market analysts / } \\
\text { investment banking. } \\
\text { Additionally, market } \\
\text { manipulation that led to legal } \\
\text { reforms structural vulnerabilities } \\
\text { in the German banking sector } \\
\text { (high cost and low market) } \\
\text { (2001-2004). }\end{array}$ & $\begin{array}{l}\text { cyclical way. From the three } \\
\text { potential shock absorbers in the } \\
\text { banking sector, two were } \\
\text { strongly deteriorated: persistent } \\
\text { low profitability across all } \\
\text { banking groups and hidden } \\
\text { reserves were worsened by } \\
\text { falling asset prices as well as } \\
\text { credit write-downs. The } \\
\text { cyclical downturn after years of } \\
\text { a domestic credit boom and the } \\
\text { burst of the "new economy" } \\
\text { stock market bubble negatively } \\
\text { impact the German financial } \\
\text { sector. Higher risk of a } \\
\text { downward spiral due to the } \\
\text { failure of financial system } \\
\text { mechanisms between the end of } \\
2002 \text { and beginning of } 2003 \text {. }\end{array}$ & $\begin{array}{l}\text { banking supervisory authority took on } \\
\text { Bankgesellschaft Berlin as a potential } \\
\text { restructuring case, due to its real estate } \\
\text { exposure losses. The so-called 'risk } \\
\text { shield' by means of guarantees and } \\
\text { injecting money was applied to } \\
\text { strengthen confidence in the financial } \\
\text { system along with Regulatory issues, } \\
\text { such as transparency and addressing the } \\
\text { conflicts of interest in the financial } \\
\text { industry. The EU commission accepted } \\
\text { these measures of state aid. }\end{array}$ \\
\hline & $\begin{array}{l}\text { During the } 2007 \text { international } \\
\text { liquidity crisis, securitizations } \\
\text { along with many underestimated } \\
\text { factors escalated the crisis, such } \\
\text { as exposure concentration and } \\
\text { market liquidity risks as banks } \\
\text { activities collapsed (in case of } \\
\text { Germany: IKB and SachsenLB). } \\
\text { However, the stressfulness of } \\
\text { SIFIs due to exposure } \\
\text { concentration, then the default of } \\
\text { Lehman Brothers prompted } \\
\text { government intervention. Some } \\
\text { German banks experienced a } \\
\text { high level of concentration to } \\
\text { CRE and excessive leverage, as } \\
\text { result higher risk of pro-cyclical } \\
\text { and the crunching of credit } \\
\text { supply. The effect extended to } \\
\text { stressed EMU sovereigns and } \\
\text { banking systems with lack of } \\
\text { comprehensive stabilization } \\
\text { policies (2007- 2017). }\end{array}$ & $\begin{array}{l}\text { Some German banks had } \\
\text { sizeable exposures to } \\
\text { commercial real estate and the } \\
\text { shipping industry. At the } \\
\text { beginning of the crisis, } \\
\text { exposures to stressed EMU } \\
\text { sovereigns and banking } \\
\text { systems were severely affected } \\
\text { the financial sector in Germany } \\
\text { due to the lack of } \\
\text { comprehensive stabilization } \\
\text { policies. Drying up of both } \\
\text { market liquidity and funding } \\
\text { liquidity led to the financial } \\
\text { crisis. The weakness of the } \\
\text { systemically important } \\
\text { financial institutions (SIFIs) } \\
\text { was also a key element after } \\
\text { bankruptcy of Lehman } \\
\text { Brothers. Accumulated } \\
\text { systemic risks were moderated } \\
\text { by domestic credit demand } \\
\text { expanding. High leverage } \\
\text { elevated the risk of pro-cyclical } \\
\text { fire sales and credit crunch. }\end{array}$ & $\begin{array}{l}\text { The liquidity crunch in some } \\
\text { institutions caused the crisis. In 2007, } \\
\text { ECB made unlimited adjustments } \\
\text { operations after Germany's KFW-bank } \\
\text { had taken over the distressed IKB } \\
\text { Deutsche Industriebank to provide } \\
\text { outsized liquidity lines to special } \\
\text { purpose vehicles. Applying measures, } \\
\text { such as substantial government } \\
\text { intervention to SIFIs, nationalization of } \\
\text { Hypo Real Estate, recapitalizations, } \\
\text { guarantees and 'risk shields'. Similar } \\
\text { measures took place at the level of } \\
\text { Bundeslaender for some } \\
\text { Landesbanken. At the European level, } \\
\text { the ESCB stabilized the situation by } \\
\text { extraordinary monetary policy } \\
\text { operations, complementarily the ESM } \\
\text { was established. }\end{array}$ \\
\hline Denmark & $\begin{array}{l}\text { Leverage and rapid credit } \\
\text { growth as early signs of crisis. } \\
\text { Strong boom caused by low } \\
\text { interest rates. A highly indebted } \\
\text { economy, large current-account } \\
\text { deficits and a structurally weak } \\
\text { labor market which required } \\
\text { strong fiscal improvements and } \\
\text { incentives for private savings } \\
(1987-1995) \text {. }\end{array}$ & $\begin{array}{l}\text { From 1987-1993, there was } \\
\text { persistent low GDP growth, } \\
\text { higher unemployment rates, a } \\
\text { highly indebted economy, large } \\
\text { current-account deficits and a } \\
\text { structurally weak labor market } \\
\text { after few years of strong } \\
\text { economic upswing. Owing to } \\
\text { the overheating of the economy } \\
\text { in the mid-1980s, strong fiscal } \\
\text { improvements and incentives } \\
\text { for private savings were } \\
\text { required. With the weak } \\
\text { Danish krone, high wage } \\
\text { increases were agreed to in } \\
\text { 1987 followed by monetary } \\
\text { tightening and market } \\
\text { interventions in the currency } \\
\text { market to defend the krone as } \\
\text { well as higher the interest rates. } \\
\text { Denmark's Nationalbank } \\
\text { provided standby liquidity }\end{array}$ & $\begin{array}{l}\text { The Danish government and Danmarks } \\
\text { Nationalbank assisted only five } \\
\text { distressed banks. They also assisted } \\
\text { Denmark's Nationalbank through } \\
\text { standby liquidity facilities for } \\
\text { Denmark's second largest bank, } \\
\text { Unibank. To defend the Krone, } \\
\text { monetary tightening and market } \\
\text { interventions in the currency market } \\
\text { were required. }\end{array}$ \\
\hline
\end{tabular}




\begin{tabular}{|c|c|c|c|}
\hline & & $\begin{array}{l}\text { facilities for Denmark's second } \\
\text { largest bank, Unibank and } \\
\text { several distressed banks. } \\
\text { Unfortunately, the crisis } \\
\text { managed to also greatly impact } \\
\text { the small and medium-sized } \\
\text { banks. }\end{array}$ & \\
\hline & $\begin{array}{l}\text { Danish Banks suffered from a } \\
\text { long period of strong lending } \\
\text { growth, a large share of } \\
\text { property-related exposures, } \\
\text { leverage and rapid credit growth } \\
(2008-2013) \text {. } \\
\text {. }\end{array}$ & $\begin{array}{l}\text { Prior to this crisis, high real } \\
\text { growth in the banks' } \\
\text { outstanding amounts of loans, } \\
\text { high lending growth, higher } \\
\text { write-downs on loans and } \\
\text { deteriorated credit quality. } \\
\text { Short-term funding through } \\
\text { international money and capital } \\
\text { markets was unstable and } \\
\text { easily affected by deposits and } \\
\text { long-term bond financing. The } \\
\text { international liquidity crisis } \\
\text { (2007) developed into a } \\
\text { genuine global credit crisis } \\
\text { later. The banks had large } \\
\text { customer funding gaps for the } \\
\text { period of strong lending } \\
\text { growth. In 2009, unexpected } \\
\text { large falls in real GDP and in } \\
\text { exports coupled with the low } \\
\text { Danish GDP and weak } \\
\text { economy, drove the county into } \\
\text { deep recession. }\end{array}$ & $\begin{array}{l}\text { To close the gaps, short-term bonds } \\
\text { provided by banks, and borrowed from } \\
\text { foreign credit institutions. Government } \\
\text { provided capital injections and gave the } \\
\text { opportunity to purchase an individual } \\
\text { government guarantee on debt issues to } \\
\text { credit institutions, thereby providing a } \\
\text { safety net for the banks through } \\
\text { comprehensive government guarantee } \\
\text { for depositors. Credit facilities and the } \\
\text { expanded collateral base were provided } \\
\text { by Denmark's Nationalbank. }\end{array}$ \\
\hline \multirow[t]{2}{*}{ Estonia } & $\begin{array}{l}\text { The loss of trade with the Soviet } \\
\text { Union in } 1990 \text { caused a trade } \\
\text { shock, the monetary policy } \\
\text { tightened, and a currency board } \\
\text { was instituted to end the post- } \\
\text { transition inflation. A severe } \\
\text { recession bottomed out in 1992- } \\
\text { 1993. Leverage and rapid credit } \\
\text { growth as early signs of crisis, } \\
\text { exposure concentration } \\
\text { mismatches and market } \\
\text { illiquidity, misaligned } \\
\text { incentives. }\end{array}$ & $\begin{array}{l}\text { The economic losses were in } \\
\text { the double-digits, due to } \\
\text { unqualified and inexperienced } \\
\text { bank managers as well as poor } \\
\text { banking sector regulation. The } \\
\text { high share of non-performing } \\
\text { assets caused liquidity } \\
\text { problems in banks. The central } \\
\text { bank enhanced banking } \\
\text { regulation and strengthened } \\
\text { banking supervision. The } 1992 \\
\text { crisis caused moratoriums in } \\
\text { three largest banks and foreign } \\
\text { exchange deposits in the Soviet } \\
\text { Vneshekonombank } \\
\text { frozen in two of them. Quick } \\
\text { measures were undertaken by } \\
\text { the central bank and } \\
\text { government to support the } \\
\text { stabilization of the banking } \\
\text { system. Many small banks } \\
\text { could not survive or be merged } \\
\text { with other banks. There was a } \\
\text { loss of confidence in the } \\
\text { Estonian banks due to the } \\
\text { delayed settlement of accounts. } \\
\text { After independence, many } \\
\text { banks and private } \\
\text { entrepreneurships } \\
\text { reestablished. }\end{array}$ & $\begin{array}{l}\text { Government and the Bank of Estonia } \\
\text { provided liquidity assistance and } \\
\text { injected capital to form new banks. A } \\
\text { part of the non-performing assets of } \\
\text { Balti Ühispank and Põhja-Eesti } \\
\text { Aktsiapank were moved into a separate } \\
\text { fund and the remaining assets were } \\
\text { transferred to Põhja-Eesti Pank. }\end{array}$ \\
\hline & $\begin{array}{l}\text { Leverage and rapid credit } \\
\text { growth as early signs of crisis, } \\
\text { exposure concentration (1994- } \\
\text { 1995). }\end{array}$ & $\begin{array}{l}\text { In 1994, Estonia had liquidity } \\
\text { problems and a large amount of } \\
\text { bad loans after the Estonian } \\
\text { government and the largest } \\
\text { municipality transferred their } \\
\text { deposits to the government- } \\
\text { owned bank. Eesti Tööstuse-ja }\end{array}$ & $\begin{array}{l}\text { In November 1994, another bank, Eesti } \\
\text { Tööstuse- ja Arengupank and Eesti } \\
\text { Sotsiaalpank merged. However, there } \\
\text { was no improvement and the } \\
\text { liquidation of the bank was announced } \\
\text { in May 1995. }\end{array}$ \\
\hline
\end{tabular}




\begin{tabular}{|c|c|c|c|}
\hline & & $\begin{array}{l}\text { Arengupank and Eesti } \\
\text { Sotsiaalpank banks had } \\
\text { difficulties even after merging } \\
\text { and lost interested investors in } \\
\text { the banking sector. Eesti Pank } \\
\text { supplied liquidity assistance as } \\
\text { well as injected capital to the } \\
\text { bank, however, the liquidation } \\
\text { of the bank was announced in } \\
\text { May 1995. }\end{array}$ & \\
\hline & $\begin{array}{l}\text { Exposure concentration, } \\
\text { misaligned incentives (June } \\
\text { 1998-April 1999). }\end{array}$ & $\begin{array}{l}\text { Higher exposure to the stock } \\
\text { market due to large amounts of } \\
\text { non-performing assets. In } \\
\text { 1997, the Asian crisis crashed } \\
\text { the stock market, which led to } \\
\text { the deterioration of the bank's } \\
\text { solvency until it went into } \\
\text { default. Some Banks were hit } \\
\text { by the stock market, and later } \\
\text { affected by the Russian crisis in } \\
\text { 1998 which caused a decline in } \\
\text { investments and losses of } \\
\text { deposits, partial default and } \\
\text { devaluation. The Bank of } \\
\text { Estonia injected capital in } \\
\text { Optiva Bank (formerly Eesti } \\
\text { Forekspank) and merged with } \\
\text { Eesti Investeerimispank. }\end{array}$ & $\begin{array}{l}\text { Partial compensation was made by the } \\
\text { Government to Eesti Maapank due to } \\
\text { the inefficiency of the deposit } \\
\text { guarantee system. Capital was } \\
\text { provided to Optiva Bank (formerly } \\
\text { Eesti Forekspank) by Bank of Estonia, } \\
\text { and then merged with Eesti } \\
\text { Investeerimispank in October 1998. }\end{array}$ \\
\hline Spain & $\begin{array}{l}\text { The banking status quo was } \\
\text { broken up and many of the } \\
\text { existing institutions had } \\
\text { insufficient funds. During } \\
1970 \text { s, the Spanish economy was } \\
\text { vulnerable due to the industrial } \\
\text { crisis. }\end{array}$ & $\begin{array}{l}\text { In the wake of the } 1962 \text { Credit } \\
\text { and Banking Law, many of the } \\
\text { existing institutions had } \\
\text { insufficient funds and were } \\
\text { vulnerable to the } 1970 \mathrm{~s} \\
\text { industrial crisis that severely hit } \\
\text { the Spanish economy. The } \\
\text { crisis was generated by general } \\
\text { economic factors, such as the } \\
\text { oil crisis and the hardest } \\
\text { inflationary episode, with price } \\
\text { dislocation, failed assessments } \\
\text { and the inevitable corrective } \\
\text { measures. }\end{array}$ & $\begin{array}{l}\text { The Deposit Guarantee Fund was } \\
\text { established by the Spanish Bank to } \\
\text { overcome the crisis and to cover } \\
\text { customer deposits of troubled } \\
\text { institutions. Moreover, the crisis } \\
\text { required a quick reconsideration of } \\
\text { bank accounting standards, } \\
\text { subsequently of prudential regulations } \\
\text { and an intense fiscal stabilization effort. }\end{array}$ \\
\hline & $\begin{array}{l}\text { Leverage and rapid credit } \\
\text { growth as early signs of crisis, } \\
\text { exposure concentration. The } \\
\text { global financial crisis, domestic } \\
\text { housing bubble and excessive } \\
\text { credit growth deeply hit the } \\
\text { Spanish economy. } \\
\text { recession period, an over- } \\
\text { exposure of savings banks to the } \\
\text { real estate sector, other EA crisis } \\
\text { and the weaknesses of the EA } \\
\text { design have escalated the 2009- } \\
2013 \text { banking crisis (2009- } \\
2013) \text {. }\end{array}$ & $\begin{array}{l}\text { The Spanish crisis had several } \\
\text { phases: economic crises due to } \\
\text { the collapse of the real estate } \\
\text { market; deep banking crisis or } \\
\text { the combination of these two } \\
\text { crises. Moreover, the distress } \\
\text { in other EU members led to } \\
\text { severe sovereign tensions in } \\
\text { 2011. However, the fiscal } \\
\text { position of Spain was relatively } \\
\text { sound, but the economic } \\
\text { recession and the banking crisis } \\
\text { exhausted the loss-absorption } \\
\text { capacity of government debt, as } \\
\text { result sovereign tensions and } \\
\text { capital flight. } \\
\text { initially was trigged by housing } \\
\text { bubble crisis, and then by the } \\
\text { international financial market } \\
\text { crisis. }\end{array}$ & $\begin{array}{l}\text { Insufficient capital and loss-absorption } \\
\text { capacity were covered by the } \\
\text { recapitalization measures, burden } \\
\text { sharing mechanisms and public funds } \\
\text { contributions in eight banking groups. } \\
\text { The introduction of new legislation on } \\
\text { savings banks and the establishment of } \\
\text { bank foundations by the corporate } \\
\text { regime to govern the savings banks } \\
\text { were warranted. With public support, } \\
\text { some banks resized through an intense } \\
\text { process of rationalizing their balance } \\
\text { sheets. To tackle the crisis, } \\
\text { unconventional monetary policies, } \\
\text { creation of the SSM, and EU political } \\
\text { measures were employed. }\end{array}$ \\
\hline Finland & $\begin{array}{l}\text { Leverage and rapid credit } \\
\text { growth as early signs of crisis } \\
\text { after deregulation of the } \\
\text { financial markets from 1991- } \\
\text { 1998. Excessive risk-taking }\end{array}$ & $\begin{array}{l}\text { Exposure concentration in } \\
\text { domestic corporate loans. Loss } \\
\text { of confidence in SKOP bank. } \\
\text { Lower interest rates and rapid } \\
\text { credit growth escalated a real }\end{array}$ & $\begin{array}{l}\text { In September 1991, the Bank of Finland } \\
\text { stepped in to save confidence in SKOP } \\
\text { Bank, and to take over control of the } \\
\text { bank to maintain the stability of } \\
\text { financial system. There were a lot of }\end{array}$ \\
\hline
\end{tabular}




\begin{tabular}{|c|c|c|c|}
\hline & $\begin{array}{l}\text { spurred by misaligned } \\
\text { incentives. }\end{array}$ & $\begin{array}{l}\text { estate bubble and overheated } \\
\text { the economy in 1988, during } \\
\text { which monetary policy was } \\
\text { constrained due the exchange } \\
\text { rate regime. The currency } \\
\text { depreciated sharply by the end } \\
\text { of } 1991 \text { and later, there were } \\
\text { defaults in business deals with } \\
\text { foreign currency obligations. } \\
\text { The economy suffered from a } \\
\text { worldwide recession, a major } \\
\text { tax reform that limited the } \\
\text { deductibility of interest } \\
\text { payments, coupled with high } \\
\text { debt burden, burst the bubble } \\
\text { and caused a recession. } \\
\text { Monetary tightening started in } \\
\text { 1989. } \\
\text { exports declined by over } 6 \% \text { as } \\
\text { well the domestic demand by } \\
\text { about } 8 \% \text { The unemployment } \\
\text { rate exceeded 10\% in 1991. } \\
\text { Collapsing the domestic } \\
\text { economic activity with a severe } \\
\text { decline in profitability that } \\
\text { worsened the banks' financial } \\
\text { position. Moreover, with the } \\
\text { collapse of Soviet Union, } \\
\text { Finland's exports were greatly } \\
\text { decreased. Many financial } \\
\text { institutes chose bankruptcy. In } \\
\text { 1992, Finnish banking had a } \\
\text { severe systematic crisis without } \\
\text { suffering any failure. For } \\
\text { example, SKOP Bank was } \\
\text { taken over by the Bank of } \\
\text { Finland. Then, the Finnish } \\
\text { banks started major } \\
\text { restructuring of the banking } \\
\text { sector, and the crisis ended in } \\
1995 \text {. Later, the Bank of } \\
\text { Finland allowed the markka's } \\
\text { exchange rate to float } \\
\text { temporarily. }\end{array}$ & $\begin{array}{l}\text { mergers in local banking groups, both } \\
\text { in savings banks and in co-operative } \\
\text { banks to handle the crisis. Some banks } \\
\text { had their banking licenses revoked, and } \\
\text { then they were converted into asset } \\
\text { management companies. In 1995, prior } \\
\text { to crisis, there was no proper legislation } \\
\text { was in place to manage the situation, } \\
\text { especially after the merger of Kansallis- } \\
\text { Osake-Pankki and Union Bank of } \\
\text { Finland to form one of the Finland's } \\
\text { largest commercial banks. }\end{array}$ \\
\hline France & During the $1990 \mathrm{~s}$ & $\begin{array}{l}\text { This crisis had complex stages. } \\
\text { France had a high GDP growth } \\
\text { and deregulation from } 1987 \text { to } \\
1990 \text { that caused a huge } \\
\text { increase in both residential and } \\
\text { commercial real estate prices. } \\
\text { A sharp decrease in } \\
\text { commercial real estate } \\
\text { properties had a negative } \\
\text { impact on the financial position } \\
\text { of borrowers and caused their } \\
\text { default, despite a bounce back } \\
\text { effect in early 1991. The ERM } \\
\text { crisis affected the European } \\
\text { partners and France in } \\
\text { September 1992; the recession } \\
\text { in real estate; the fragile state of } \\
\text { the banking sector and the near } \\
\text { bankruptcy of the Crédit } \\
\text { Lyonnais due to real estate } \\
\text { market downturn and a risky } \\
\text { business model strategy. } \\
\text { Second, due to the non- } \\
\text { performing loans and the fall in }\end{array}$ & None. \\
\hline
\end{tabular}




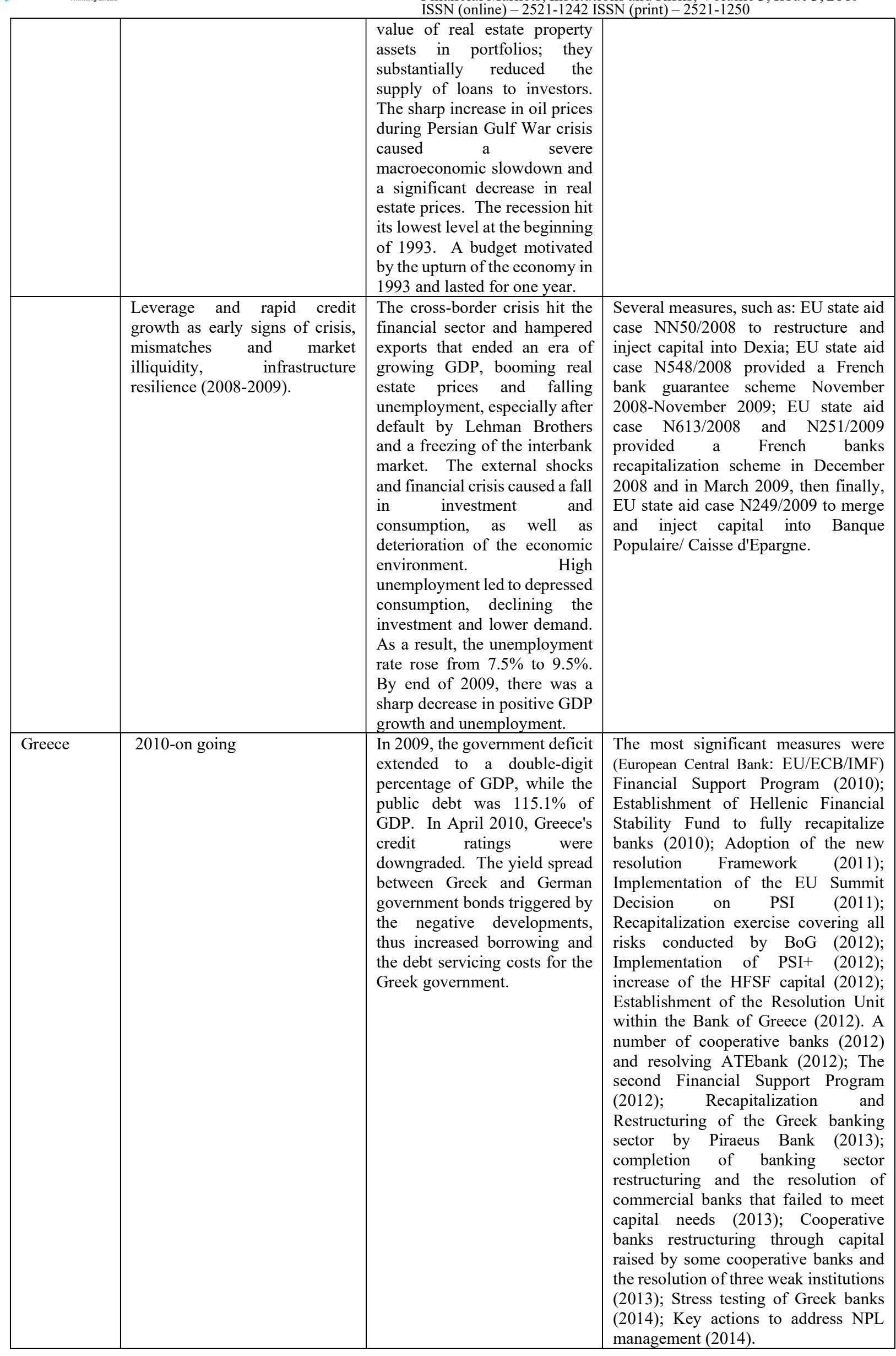




\begin{tabular}{|c|c|c|c|}
\hline Croatia & $\begin{array}{l}\text { During the 1990s' transition, } \\
\text { Croatia faced many challenges, } \\
\text { such as heavy state involvement } \\
\text { in real sector; weak corporate } \\
\text { governance; harmful } \\
\text { privatization process and weak } \\
\text { institutional framework. } \\
\text { Ineffective banking supervision } \\
\text { system to enforce prudent } \\
\text { governance in banks. Moreover, } \\
\text { weak bank regulations allowed a } \\
\text { number of private agents with } \\
\text { insufficient capacities to engage } \\
\text { in banking activities. The } \\
\text { Private Banks provided cheap } \\
\text { financings to founding } \\
\text { companies (exposure } \\
\text { concentration, misaligned } \\
\text { incentives). }\end{array}$ & $\begin{array}{l}\text { The financial difficulties } \\
\text { spread across the banking } \\
\text { system, particularly in the fifth } \\
\text { largest bank, then affected } \\
\text { other inadequately governed } \\
\text { institutions. Banking crisis did } \\
\text { not affect the real estate sector. } \\
\text { In 1996, the government } \\
\text { finalized the resolution process } \\
\text { by writing-offs of NPLs, } \\
\text { recapitalizing three large } \\
\text { banks, and then sold them to } \\
\text { foreign financial institutions by } \\
\text { the end of } 1999 \text { and early } 2000 \text {. } \\
\text { Additionally, banks increased } \\
\text { their market share by credit } \\
\text { expansion as well as very } \\
\text { aggressive interest rate policies } \\
\text { (excessive credit growth). } \\
\text { Many systematic risks } \\
\text { accumulated in the banking } \\
\text { sectors. Due to extensive credit } \\
\text { losses, a few banks defaulted } \\
\text { during transition period. }\end{array}$ & $\begin{array}{l}\text { In 1998, government assistance to the } \\
\text { fifth largest bank. However, three were } \\
\text { major losses in several other medium- } \\
\text { sized and small banks that led to a surge } \\
\text { in deposit outflows and a loss } \\
\text { confidence. In 1996, failure of the } \\
\text { recapitalization process from public } \\
\text { resources led to bankruptcy procedures } \\
\text { as well as privatizing three large banks. } \\
\text { Low interest rates encouraged lending } \\
\text { using the emergency liquidity facility } \\
\text { as a part of the measurements of the } \\
\text { monetary authorities and the central } \\
\text { bank. }\end{array}$ \\
\hline & $\begin{array}{l}\text { The global financial crisis } \\
\text { caused a slowdown in capital } \\
\text { inflows, an abrupt contraction of } \\
\text { the domestic demand as well as } \\
\text { insufficient external demand } \\
\text { which hindered the recovery. } \\
\text { The Croatian economy faced a } \\
\text { major structural growth crisis. } \\
\text { The failure of a few small private } \\
\text { banks caused the inability to } \\
\text { survive in a long-lasting } \\
\text { recessionary environment, heavy } \\
\text { exposure to the SME among } \\
\text { others. During the transition } \\
\text { period, several banks lost } \\
\text { capital, so state funds were } \\
\text { injected (2007-2012). }\end{array}$ & $\begin{array}{l}\text { The collapse of Lehman } \\
\text { Brothers caused a global risk } \\
\text { and high price volatility as well } \\
\text { as a fall in liquidity and } \\
\text { unpredictable markets. The } \\
\text { financial system and exchange } \\
\text { rate were stable, but the } \\
\text { government repaid the } \\
\text { maturing debts according to the } \\
\text { countercyclical monetary and } \\
\text { macroprudential policy of the } \\
\text { central bank. The risk } \\
\text { premiums in Croatia increased, } \\
\text { and stress spread to the } \\
\text { domestic financial system } \\
\text { through foreign financial } \\
\text { markets. International debt } \\
\text { market conditions worsened } \\
\text { with higher CDS premiums for } \\
\text { the parent banks of the five } \\
\text { largest domestic banks. } \\
\text { Adverse developments in CDS } \\
\text { premiums increased the risk } \\
\text { perception of Italian parent } \\
\text { banks compared to other } \\
\text { countries, such as Austria or } \\
\text { France. A partial withdrawal of } \\
\text { the parent banks funding } \\
\text { increased pressures on the } \\
\text { foreign currency liquidity and a } \\
\text { higher level of stress due to the } \\
\text { international securities. } \\
\text { Parent institutions of domestic } \\
\text { banks financed excessive credit } \\
\text { growth that led to high level of } \\
\text { current account deficit and } \\
\text { increased foreign debt while } \\
\text { the competitiveness indicators } \\
\text { declined. Weak financial } \\
\text { markets with limited supply } \\
\text { pressured the domestic } \\
\text { currency exchange rate and } \\
\text { financial assets' prices. A } \\
\text { strong credit activity, declining }\end{array}$ & $\begin{array}{l}\text { During the global financial crisis, the } \\
\text { CNB gradually released the previously } \\
\text { established banking system's liquidity } \\
\text { reserves to facilitate the domestic } \\
\text { sectors due to the collapse of Lehman } \\
\text { Brothers after a panic episode by } \\
\text { domestic depositors. The CNB } \\
\text { supported the foreign currency } \\
\text { liquidity. In 2004, the marginal reserve } \\
\text { requirements (MRR) were applied to } \\
\text { slow down the growth of banks' } \\
\text { external debt by allocating a significant } \\
\text { share of their net foreign borrowing into } \\
\text { a special account held with the central } \\
\text { bank (above } 50 \% \text { ) as interest-free } \\
\text { foreign currency deposits. In late } 2008 \text {, } \\
\text { CNB reduced the general reserve } \\
\text { requirement rate to } 14 \% \text { to improve the } \\
\text { domestic financing conditions for the } \\
\text { corporate sector. However, the } \\
\text { government needed substantial } \\
\text { financing aid. Weak currency occurred } \\
\text { due to limited net inflow of foreign } \\
\text { capital which reduced the minimum } \\
\text { required foreign currency claims rate to } \\
20.0 \% \text { at the beginning of } 2009 \text {, } \\
\text { releasing even more foreign exchange } \\
\text { liquidity. Adjustments of substantial } \\
\text { foreign currency liquidity provided } \\
\text { exchange rate stability and overall } \\
\text { financial stability of the economy. The } \\
\text { Croatian banking sector was under } \\
\text { control and very well capitalized during } \\
\text { the crisis. No fiscal interventions were } \\
\text { required for banks' resolution. Lending } \\
\text { declined and the economy recovered in } \\
\text { early February } 2010 \text {. The CNB } \\
\text { lowered the minimum required foreign } \\
\text { currency claims rate to } 17 \% \text { to improve } \\
\text { banks' credit potential, decrease banks' } \\
\text { regulatory costs, while lending rates } \\
\text { improved financing conditions for the } \\
\text { corporate and household sectors. The } \\
\text { European debt markets hit the Croatian }\end{array}$ \\
\hline
\end{tabular}




\begin{tabular}{|c|c|c|c|}
\hline & & 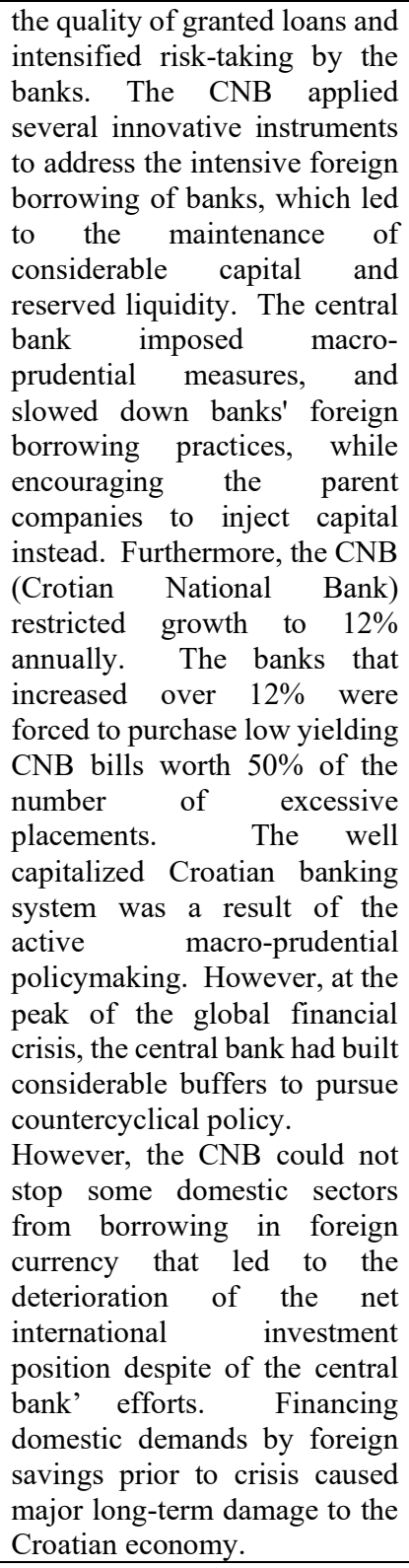 & $\begin{array}{l}\text { economy deeply by the mid-2011, the } \\
\text { increase in the cost of foreign } \\
\text { borrowing plus the withdrawal of } \\
\text { parent banks' funding had led to } \\
\text { depreciation pressures on the kuna } \\
\text { exchange rate. } \\
\text { The central bank participated in four } \\
\text { foreign exchange interventions to } \\
\text { maintain the relatively stable exchange } \\
\text { rate. In October 2013, the CNB } \\
\text { switched to a rules-based approach } \\
\text { which required banks to valuate assets } \\
\text { more objectively, to spot credit losses } \\
\text { in time so that banks engaging in debt } \\
\text { restructurings (evergreening of loans). } \\
\text { Due to low liquidity of the real estate } \\
\text { market, there was a strong increase in } \\
\text { provisioning costs that negatively } \\
\text { reflected on banks earnings, which } \\
\text { successfully encouraged banks to speed } \\
\text { up the process of NPL resolution. }\end{array}$ \\
\hline \multirow[t]{2}{*}{ Hungary } & $\begin{array}{l}\text { There was a severe recession } \\
\text { despite of enacting bankruptcy } \\
\text { legislation in 1992, enterprise } \\
\text { restructuring was doomed by } \\
\text { inadequate reforms to bank } \\
\text { lending policies. The current } \\
\text { account deficit was almost } 10 \% \\
\text { of GDP during 1993-94, and the } \\
\text { external debt rose to higher } \\
\text { level. The fiscal deficit grew to } \\
8 \% \text { of GDP in } 1994 \text { and a } \\
\text { crawling currency was } \\
\text { introduced in } 1995 \text {. } \\
\text { Stabilization and growth were } \\
\text { hampered and there was heavy } \\
\text { foreign borrowing by enterprises } \\
\text { during 1994-95, and strong } \\
\text { capital inflows in the second half } \\
\text { of } 1995 \text {. }\end{array}$ & $\begin{array}{l}\text { During the transition period, } \\
\text { excessive loans caused } \\
\text { insolvent enterprises. Banks } \\
\text { had insufficient capital, were } \\
\text { improperly regulated and were } \\
\text { unrestricted controlled by } \\
\text { unqualified owners. The high } \\
\text { inflation was reduced after the } \\
\text { transition period. The } \\
\text { accumulation of Hungarian FX } \\
\text { loans remained along with high } \\
\text { household indebtedness and } \\
\text { vulnerability of the Hungarian } \\
\text { government. The excessive } \\
\text { credit growth was caused by } \\
\text { high reliance on short-term } \\
\text { debt and derivative } \\
\text { instruments. HUF sharply } \\
\text { depreciated against CHF while } \\
\text { the material credit and } \\
\text { refinancing risks grew. }\end{array}$ & $\begin{array}{l}\text { Crisis was solved by Injection of state } \\
\text { funds. }\end{array}$ \\
\hline & $\begin{array}{l}2007 \text { international liquidity } \\
\text { crisis }\end{array}$ & $\begin{array}{l}\text { The crisis was imported due to } \\
\text { the interconnectedness of }\end{array}$ & $\begin{array}{l}\text { In order to restore investors' } \\
\text { confidence, there was an ease in }\end{array}$ \\
\hline
\end{tabular}




\begin{tabular}{|c|c|c|c|}
\hline & & $\begin{array}{l}\text { financial intermediaries and } \\
\text { high external weakness of the } \\
\text { domestic financial system in } \\
\text { Europe. The frozen } \\
\text { international money market hit } \\
\text { the Hungarian economy hard. } \\
\text { During the crisis, financing the } \\
\text { public and banking sector was } \\
\text { hindered by the foreign } \\
\text { exchange and the renewal of } \\
\text { swaps risks. Additionally, the } \\
\text { public sector's budget deficit } \\
\text { increased, in addition to higher } \\
\text { levels of local currency interest } \\
\text { rates. Low funding costs } \\
\text { caused an increase in the } \\
\text { foreign currency-denominated } \\
\text { loans. Furthermore, there was } \\
\text { a decline in the international } \\
\text { money markets and a build-up } \\
\text { of vulnerability in the } \\
\text { Hungarian banking sector } \\
\text { where most of the loans were in } \\
\text { foreign currency (mainly Swiss } \\
\text { francs). As a result, the } \\
\text { banking sector experienced an } \\
\text { increased rate of non- } \\
\text { performing loans, followed by } \\
\text { deteriorated profitability during } \\
\text { the downturn. }\end{array}$ & $\begin{array}{l}\text { financing and liquidity tensions. } \\
\text { Governmental loans were provided for } \\
\text { commercial banks. Unconventional } \\
\text { monetary policy measures addressed } \\
\text { the weak bank lending activity. }\end{array}$ \\
\hline Ireland & $\begin{array}{l}\text { The crisis emerged in the } \\
\text { domestic banking sector. The } \\
\text { main Irish banks generated } \\
\text { revenue by using cheap sources } \\
\text { of short-term wholesale funding } \\
\text { during real estate market crisis. } \\
\text { The leverage of domestic private } \\
\text { sector increased pre-crisis as } \\
\text { well as indebtedness. The } \\
\text { excessive credit growth, } \\
\text { excessive maturity mismatch, } \\
\text { Concentration risk unified with } \\
\text { dangers of misaligned incentives } \\
\text { during the Irish crisis of 2008- } \\
\text { 2013. }\end{array}$ & $\begin{array}{l}\text { The Irish banks had significant } \\
\text { liquidity problems due to } \\
\text { global debt markets, domestic } \\
\text { macroeconomic imbalances } \\
\text { and unstainable banking sector } \\
\text { strategies. In terms of } \\
\text { macroeconomic imbalances, a } \\
\text { pro-cyclical fiscal policy } \\
\text { position and policies that } \\
\text { coincided with favorable } \\
\text { domestic demand factors, the } \\
\text { banking sector was largely } \\
\text { funded construction/property } \\
\text { boom by relying on cheap } \\
\text { sources of external wholesale } \\
\text { borrowing. }\end{array}$ & $\begin{array}{l}\text { The scale of the banking crisis required } \\
\text { intervention, and was significant due to } \\
\text { frozen international funding markets. } \\
\text { Guarantees on certain types of } \\
\text { liabilities, expansion of the Deposit } \\
\text { Guarantee Scheme, recapitalizations of } \\
\text { domestic banks, nationalizations of } \\
\text { some domestic banks, establishment of } \\
\text { an asset management agency (i.e., } \\
\text { NAMA). Targeted deleveraging, fiscal } \\
\text { consolidation measures and structural } \\
\text { reforms (ECB/IMF/EU Program) for } \\
\text { external assistance were all required. } \\
\text { The emergency liquidity assistance was } \\
\text { extended and nationalization the } \\
\text { Anglo-Irish Bank. }\end{array}$ \\
\hline \multirow[t]{2}{*}{ Italy } & $\begin{array}{l}\text { Leverage and rapid credit } \\
\text { growth as early signs of crisis, } \\
\text { exposure concentration. During } \\
\text { the } 1990 \text { s, several public-owned } \\
\text { banks were affected by } \\
\text { allocative and cost } \\
\text { inefficiencies, and then severely } \\
\text { hit by the strong recession. } \\
\text { Italian banks had to increase } \\
\text { their exposures toward riskier } \\
\text { borrowers from 1991-1997. }\end{array}$ & $\begin{array}{l}\text { Unstable currency markets and } \\
\text { connected with the ERM crisis } \\
\text { (the Lira exited the ERM) hit } \\
\text { the Italian economy hard, a } \\
\text { large number of small banks in } \\
\text { the south were in distress in the } \\
\text { ' } 90 \text { s. }\end{array}$ & $\begin{array}{l}\text { The crisis was managed through usual } \\
\text { instruments and in line with private } \\
\text { market solutions. Poor management } \\
\text { caused weakness in two large Italian } \\
\text { banks (Sicilcassa and Banco di Napoli), } \\
\text { and then bank sector fell into the } \\
\text { political sphere. Two banks were } \\
\text { becoming privatized after applying for } \\
\text { reconstruction reforms. Various forms } \\
\text { of public interventions were applied } \\
\text { and had an impact of } 0.5 \% \text { in terms of } \\
1996 \text { GDP. }\end{array}$ \\
\hline & $\begin{array}{l}\text { Tensions in the sovereign bonds } \\
\text { markets in the euro area from } \\
2011-2013 \text {. }\end{array}$ & $\begin{array}{l}\text { The instability was caused by } \\
\text { tensions in the sovereign bonds } \\
\text { markets in the euro zone. As a } \\
\text { result, the Italian economy } \\
\text { developed three main } \\
\text { transmission channels: } \\
\text { Banking channel: Banks could } \\
\text { not generate funds due to the } \\
\text { deterioration of sovereign }\end{array}$ & $\begin{array}{l}\text { Several monetary policy measures were } \\
\text { taken by the Eurosystem to assist the } \\
\text { euro-area banks obtain liquidity. } \\
\text { Several interventions at the European } \\
\text { institutional level to improve risk were } \\
\text { aimed to strengthen financial system } \\
\text { stability and to restore market } \\
\text { confidence. Banks' funding difficulties } \\
\text { were largely eased by the ECB's }\end{array}$ \\
\hline
\end{tabular}




\begin{tabular}{|c|c|c|c|}
\hline & & $\begin{array}{l}\text { creditworthiness in terms of } \\
\text { higher cost of credit and } \\
\text { unavailability of loans through } \\
\text { the traditional bank lending } \\
\text { channel. Increasing the Banks' } \\
\text { cost of funding significantly as } \\
\text { well as the cost of new loans to } \\
\text { non-financial corporations and } \\
\text { households in } 2011 \text {. } \\
\text { Confidence channel: The EU's } \\
\text { sovereign debt crisis had an } \\
\text { impact on businesses and on } \\
\text { consumer confidence. The } \\
\text { crisis was magnified by many } \\
\text { factors: fiscal consolidation } \\
\text { policies (i.e. cuts on } \\
\text { government spending and/or } \\
\text { tax increases) to recover public } \\
\text { finances; the negative } \\
\text { developments in the equity and } \\
\text { the bond markets were the } \\
\text { reason for the internal and } \\
\text { external financing of of } \\
\text { investment expensive and } \\
\text { affected consumption and the } \\
\text { deterioration of the economic } \\
\text { outlook. The impact of } \\
\text { Trade and financial linkages } \\
\text { channel: } \\
\text { sovereign debt markets had a } \\
\text { continental effect through } \\
\text { international trade } \\
\text { financial linkages. During the } \\
\text { sovereign debt crisis Italian } \\
\text { intra-EMU, exports decreased } \\
\text { markedly. }\end{array}$ & $\begin{array}{l}\text { decisions to reduce the official rates at } \\
\text { the end of } 2011 \text {, also by launching the } \\
\text { two 3-year longer-term refinancing } \\
\text { operations. In mid-2012, due to } \\
\text { emerging economies, a large inflow of } \\
\text { capital and structural reforms made the } \\
\text { economy more resilient to forthcoming } \\
\text { shocks. In 2013, the financial } \\
\text { conditions improved due to the crucial } \\
\text { contribution of monetary policy. }\end{array}$ \\
\hline Lithuania & $\begin{array}{l}\text { Lack of proper legislation, weak } \\
\text { bank regulation, low bank } \\
\text { capitalization levels and } \\
\text { excessive risk taking. The weak } \\
\text { internal environment, difficulties } \\
\text { to measure the riskiness of bank } \\
\text { borrowers and poor bank loan } \\
\text { portfolios led to excessive credit } \\
\text { growth to risky borrowers. } \\
\text { Borrowers started defaulting on } \\
\text { their loans, and then banks were } \\
\text { unable to maintain sufficient } \\
\text { liquidity. Expansionary } \\
\text { monetary policy and supply } \\
\text { shortages led to hyperinflation } \\
\text { from } 1992 \text { to } 1993 \text {. There also } \\
\text { was a credit crunch and } \\
\text { recession from } 1991 \text { to } 1993 \text {. }\end{array}$ & $\begin{array}{l}\text { During deflation, many } \\
\text { borrowers were unable to repay } \\
\text { loans and the number of bad } \\
\text { loans rose. Moreover, bank } \\
\text { profit margins fell } \\
\text { dramatically. From 1994- } \\
\text { 1996, the banks' insolvency } \\
\text { problems led to a loss of } \\
\text { confidence in the banking } \\
\text { sector and a freeze on interbank } \\
\text { market lending. The crisis was } \\
\text { caused by insufficient banking } \\
\text { regulation and supervision at } \\
\text { the micro level as well as an } \\
\text { undeveloped banking sector. }\end{array}$ & $\begin{array}{l}\text { The Lithuanian parliament adopted } \\
\text { crisis management policies, such as: } \\
\text { 1. Increasing banks' liabilities } \\
\text { to shareholders and board } \\
\text { members. } \\
\text { 2. } \quad \text { Number of legislations } \\
\text { required in case of banks' } \\
\text { insolvency via government } \\
\text { interventions channels. } \\
\text { Liquidity loans and } \\
\text { purchased government } \\
\text { securities from troubled } \\
\text { banks by Bank of Lithuania. } \\
\text { An ease on this requirement } \\
\text { for commercial banks was } \\
\text { temporarily lifted. }\end{array}$ \\
\hline & $\begin{array}{l}\text { Lithuania's banking sector had } \\
\text { extensive and unbalanced credit } \\
\text { growth. Looseness of bank } \\
\text { credit standards affected the } \\
\text { quality of the banks' balance } \\
\text { sheets. Furthermore, extensive } \\
\text { credit growth and high housing } \\
\text { prices led to increase the private } \\
\text { debt and (subsequently) to credit } \\
\text { defaults (2004-2008). }\end{array}$ & $\begin{array}{l}\text { The crisis was caused by both } \\
\text { external and internal factors. } \\
\text { Investment started slowing } \\
\text { down due to the lack of } \\
\text { confidence related to the weak } \\
\text { macroeconomic environment } \\
\text { when GDP growth became } \\
\text { negative. Reduced economic } \\
\text { activity, increased private debt, } \\
\text { high housing prices and high } \\
\text { nominal interest rates led to an } \\
\text { increase in non-performing }\end{array}$ & $\begin{array}{l}\text { Government intervention increased the } \\
\text { deposit insurance limit. The Bank of } \\
\text { Lithuania lowered the mandatory } \\
\text { reserve requirement to } 4 \% \text {. }\end{array}$ \\
\hline
\end{tabular}




\begin{tabular}{|c|c|c|c|}
\hline & & $\begin{array}{l}\text { loans and a sharp tightening of } \\
\text { bank credit standards. } \\
\text { Lithuania suffered from low } \\
\text { house prices and an economic } \\
\text { slowdown. In late 2009, the } \\
\text { Lithuanian parliament } \\
\text { increased the deposit insurance } \\
\text { limit to end the crisis. }\end{array}$ & \\
\hline Luxembourg & $\begin{array}{l}\text { Exposure } \\
\text { excessive concentration, } \\
\text { moral hazard. The crisis was } \\
\text { caused by sovereign debt of The } \\
\text { Dexia, Lehman Brothers, the } \\
\text { Icelandic banks and the Greek } \\
\text { sovereign debt crisis. (2008- } \\
2010) \text {. }\end{array}$ & $\begin{array}{l}\text { The troubled Luxembourger } \\
\text { financial system and the } \\
\text { bankruptcy of Dexia. The } \\
\text { origin of the Dexia's crisis was } \\
\text { complex and partially related to } \\
\text { the collapse of Lehman } \\
\text { Brothers and the sovereign debt } \\
\text { crisis. The Luxembourg } \\
\text { economy is relatively small and } \\
\text { highly connected to the euro } \\
\text { area. }\end{array}$ & $\begin{array}{l}\text { The governments of Belgium, } \\
\text { Netherlands and Luxembourg got } \\
\text { involved to save Fortis. Capital was } \\
\text { injected after the Luxembourger } \\
\text { government acquired approximately } \\
50 \% \text { of the Fortis' equity. In October } \\
2008 \text {, Fortis emerged in Belgium and } \\
\text { Luxembourg, but was renamed as BGL } \\
\text { in Luxembourg. The stress ended } \\
\text { October } 2010 \text { when the bank was } \\
\text { ultimately incorporated into BGL BNP } \\
\text { Paribas. Finally, Dexia was } \\
\text { restructured by the Belgian government } \\
\text { in } 2011 \text {. }\end{array}$ \\
\hline \multirow[t]{2}{*}{ Latvia } & $\begin{array}{l}\text { There was a sharp decline in the } \\
\text { Latvian economy and in bank } \\
\text { profit margins on trade financing } \\
\text { when inflation was reduced from } \\
\text { almost } 100 \% \text { in } 1992 \text { to } 26 \% \text { in } \\
1994 \text {. A term of trade shock and } \\
\text { the collapse of the eastern } \\
\text { markets occurred early in the } \\
\text { transition. The crisis was trigged } \\
\text { during transitional phase of the } \\
\text { Latvian economy by insufficient } \\
\text { financial sector regulatory } \\
\text { framework, poor corporate } \\
\text { governance and fraudulent } \\
\text { activities of the banks. }\end{array}$ & $\begin{array}{l}\text { In } 1995 \text {, the banking crisis was } \\
\text { due to the transitional phase of } \\
\text { the Latvian economy which } \\
\text { was exacerbated by the } \\
\text { immature and weak regulatory } \\
\text { framework of the financial } \\
\text { system. Many banks had poor } \\
\text { corporate governance and risk } \\
\text { management practices, so they } \\
\text { were unable to absorb losses } \\
\text { after relying on speculative and } \\
\text { opportunistic bets on macro- } \\
\text { financial developments. } \\
\text { Moreover, the key causes of } \\
\text { banks' insolvencies were due to } \\
\text { fraudulent activities. }\end{array}$ & $\begin{array}{l}\text { Further strengthening and } \\
\text { developments to the financial sector } \\
\text { regulatory framework. }\end{array}$ \\
\hline & $\begin{array}{l}\text { Leverage and rapid credit } \\
\text { growth as early signs of crisis; } \\
\text { high dependence on the market } \\
\text { funding of one of the largest } \\
\text { banks in the country; exposure } \\
\text { concentration; moral hazard and } \\
\text { misaligned incentives ("too big } \\
\text { to fail"); and an unfavorable } \\
\text { external environment from } \\
\text { 2008-2010. }\end{array}$ & $\begin{array}{l}\text { Prior to the financial crisis, } \\
\text { economic growth was driven } \\
\text { by foreign capital inflows } \\
\text { which led to excessive credit } \\
\text { and real estate sector } \\
\text { developments. As tensions in } \\
\text { the international capital } \\
\text { markets increased, the financial } \\
\text { soundness of the second largest } \\
\text { bank came into question until it } \\
\text { was nationalized at the end of } \\
\text { 2008. As foreign capital } \\
\text { inflows were hindered, the } \\
\text { Latvian economy had to } \\
\text { undergo a large cyclical and } \\
\text { structural adjustment. The non- } \\
\text { performing loans rose sharply } \\
\text { as the economy began a } \\
\text { massive pay off process. }\end{array}$ & $\begin{array}{l}\text { The Latvian Government took over the } \\
\text { second largest bank in terms of assets - } \\
\text { Parex Banka. The Goverment support } \\
\text { to Parex Banka consisted of both capital } \\
\text { and liquidity injections, as well as state } \\
\text { guarantees to roll-over Parex Banka's } \\
\text { funding in a form of syndicated loans. }\end{array}$ \\
\hline Netherlands & $\begin{array}{l}\text { Despite the fact that the Dutch } \\
\text { banks were too big to fail, } \\
\text { mismatches and market } \\
\text { illiquidity motivated by all } \\
\text { vulnerabilities played an } \\
\text { important role (except in } \\
\text { infrastructure resilience). The } \\
\text { first trouble that the Dutch } \\
\text { financial institutions faced was } \\
\text { funding problems (excessive }\end{array}$ & $\begin{array}{l}\text { Severe funding problems were } \\
\text { experienced. High leverage and } \\
\text { higher levels of dependency on } \\
\text { market funding exposed the } \\
\text { Dutch banks to the shocks that } \\
\text { hit the global funding markets. } \\
\text { The combination of the global } \\
\text { financial crisis and credit } \\
\text { exposure impacted the Dutch }\end{array}$ & $\begin{array}{l}\text { Nationalization of Fortis ABN AMRO, } \\
\text { provided capital to banks and insurance } \\
\text { companies, a funding guarantee } \\
\text { scheme, an increase of the insured } \\
\text { amount under DGS, ultra-easy } \\
\text { monetary policy as well as fiscal } \\
\text { stimulus in } 2009 \text { and again in } 2010 \text {. }\end{array}$ \\
\hline
\end{tabular}




\begin{tabular}{|c|c|c|c|}
\hline & $\begin{array}{l}\text { leverage and maturity mismatch) } \\
\text { which were worsened by } \\
\text { exposure to concentrations. }\end{array}$ & $\begin{array}{l}\text { financial sector as well as the } \\
\text { deep recession in } 2009 \text {. }\end{array}$ & \\
\hline \multirow[t]{2}{*}{ Norway } & $\begin{array}{l}\text { During the } 1970 \text { s and the } 1980 \mathrm{~s} \text {, } \\
\text { the Norwegian economy had a } \\
\text { period of excessive credit } \\
\text { growth and leverage due to the } \\
\text { softness of bank capital } \\
\text { requirements. }\end{array}$ & $\begin{array}{l}\text { Excessive loan growth } \\
\text { occurred after the lifting of the } \\
\text { quantitative regulation of bank } \\
\text { lending in } 1984 \text { which led to a } \\
\text { sharp decline in both residential } \\
\text { and non-residential real estate } \\
\text { prices. Additionally, the } \\
\text { monetary policy was pro- } \\
\text { cyclical with the Norwegian } \\
\text { krone, higher German interest } \\
\text { rate, lower inflation, changes in } \\
\text { the tax rules, thus higher after- } \\
\text { tax real rate of interest above } \\
\text { the } 7 \% \text { in } 1992 \text {. Many small } \\
\text { banks failed caused by higher } \\
\text { losses on their loan books from } \\
1988 \text { to } 1990 \text {. A year later two } \\
\text { of the three largest banks } \\
\text { collapsed and largest bank had } \\
\text { severe loan losses in } 1992 \text {. }\end{array}$ & $\begin{array}{l}\text { A write down of equity and instruments } \\
\text { of ownership was cancelled according } \\
\text { to bank losses. Deposit guarantee funds } \\
\text { assisted acquisitions of failed banks. } \\
\text { Injection of new capital into the larger } \\
\text { failed banks, reduction of management } \\
\text { costs, and restructuring their lending } \\
\text { policies. The Central bank helped } \\
\text { Norwegian banking sector and by the } \\
\text { end of 1993, the second largest bank } \\
\text { raised new equity in the market. }\end{array}$ \\
\hline & $\begin{array}{l}\text { Market liquidity problems } \\
(2008-2009) .\end{array}$ & $\begin{array}{l}\text { The Norwegian interbank } \\
\text { market was affected by both the } \\
\text { failure of Lehman Brothers and } \\
\text { the freeze on international } \\
\text { funding markets, which caused } \\
\text { a halt in operation. } \\
\text { Nevertheless, } \\
\text { banks did not have credit } \\
\text { losses, but they incurred higher } \\
\text { funding costs. }\end{array}$ & $\begin{array}{l}\text { Liquidity problems were tackled by the } \\
\text { generous general supply of central bank } \\
\text { liquidity. The Norwegian State Finance } \\
\text { Fund supported the troubled banks with } \\
\text { an injection of capital. }\end{array}$ \\
\hline Poland & $\begin{array}{l}\text { During the recession period in } \\
1990-91 \text {, banks raised interest } \\
\text { rate spreads to overcome the } \\
\text { problems. } \\
\text { enterprises was too risky and } \\
\text { banks preferred to lend to the } \\
\text { government. } \\
\text { The Hyperinflation that followed } \\
\text { the transition ended in 1990-91, } \\
\text { and the fiscal deficit was } \\
\text { reduced. Economic } \\
\text { inefficiencies in the centrally } \\
\text { planned economy (low } \\
\text { productivity of foreign debt- } \\
\text { financed investments) and the } \\
\text { external shocks, such as the oil } \\
\text { crisis and globally rapid increase } \\
\text { in interest rates from 1981-1994. }\end{array}$ & $\begin{array}{l}\text { The root of the crisis was } \\
\text { foreign public debt growth in } \\
\text { concert with the inoperative } \\
\text { centrally planned communist } \\
\text { economy, oil price shocks and } \\
\text { rising global interest rates } \\
\text { which resulted in a loss of } \\
\text { creditworthiness and an } \\
\text { increase in both the risk } \\
\text { premium and cost of } \\
\text { borrowing. The rapid growth of } \\
\text { the public debt in the } 1970 \text { s } \\
\text { brought positive economic } \\
\text { impact as debts were paid off } \\
\text { by importing of foreign goods, } \\
\text { licenses and technology which } \\
\text { were a considered as source of } \\
\text { foreign currency. However, } \\
\text { with the inefficiencies in the } \\
\text { centrally planned economy and } \\
\text { a competitive global market, } \\
\text { Poland ran a trade deficit. } \\
\text { By end of } 1975 \text {, Poland faced } \\
\text { insolvency. Poland relied on } \\
\text { new loans to pay off old loans } \\
\text { which accelerated the growth } \\
\text { of the indebtedness. US trade } \\
\text { sanctions affected the Polish } \\
\text { economy until } 1987 \text { As a } \\
\text { result, the economic crisis } \\
\text { worsened, as well as the loss of } \\
\text { creditworthiness which led to } \\
\text { an increase in the risk premium } \\
\text { and the cost of borrowing. }\end{array}$ & $\begin{array}{l}\text { Several regulatory steps were taken by } \\
\text { the Polish government to regain the } \\
\text { balance in the economy, to halt the } \\
\text { growing domestic demand and } \\
\text { excessive investments. These measures } \\
\text { were inefficient and required } \\
\text { renegotiation of the loan's payment } \\
\text { terms. Multiple agreements were } \\
\text { introduced to reschedule debt, but } \\
\text { proved unsuccessful until restructuring } \\
\text { in } 1991 \text { and } 1994 \text {. The Polish financial } \\
\text { system had been a mono-bank system, } \\
\text { so there were no financial sector } \\
\text { interventions until independence in } \\
\text { January } 1989 \text {. }\end{array}$ \\
\hline
\end{tabular}




\begin{tabular}{|c|c|c|c|}
\hline & 1992-1996 & $\begin{array}{l}\text { The bank sector suffered from } \\
\text { the following: lack of economic } \\
\text { incentives in the centrally } \\
\text { planned economy prior to } 1989 \text {, } \\
\text { mismanagement and rapid } \\
\text { growth of the sector in the } \\
1990 \text { 's which negatively } \\
\text { affected the resilience of the } \\
\text { system. The banking sector } \\
\text { was incapable of facing the } \\
\text { economic turmoil in the early } \\
\text { 1990's. } \\
\text { During the transition process } \\
\text { 1989-1990, most loans were } \\
\text { owned by two state companies. } \\
\text { An episode of high/hyper- } \\
\text { inflation as well as high interest } \\
\text { rates pushed some borrowers } \\
\text { into debt spirals. Then, the } \\
\text { banking sector in Poland } \\
\text { experienced problems, such as } \\
\text { an unrestrained credit policy, } \\
\text { rapid uncontrolled growth, } \\
\text { insufficient or lack of control of } \\
\text { mechanisms and corporate } \\
\text { governance, a low level of } \\
\text { capital, inexperienced } \\
\text { managerial staff and weak } \\
\text { prudential regulations. }\end{array}$ & $\begin{array}{l}\text { The main focus of NBP (National Bank } \\
\text { of Poland) and the government } \\
\text { interventions were to restore trust in the } \\
\text { banking sector. In 1993, the } \\
\text { government had partially guaranteed } \\
\text { "bad loans" and commenced issuing } \\
\text { restructuring bonds that were } \\
\text { transferred to the banks in order to } \\
\text { recapitalize. Together with other } \\
\text { transfers, the support for the banking } \\
\text { system reached to } 2.7 \% \text { of } 1996 \text { GDP. } \\
\text { In } 1995 \text {, the Bank Guarantee Fund was } \\
\text { established, nevertheless with a limited } \\
\text { scale of guarantees. The NBP took } \\
\text { some measures to provide liquidity in } \\
\text { the market, such as suspension of the } \\
\text { obligation to keep capital at the central } \\
\text { bank and open access to refinancing } \\
\text { loans. To improve the resilience of the } \\
\text { system, the banking licenses were } \\
\text { tightened and the banks were } \\
\text { encouraged to consolidate. The larger } \\
\text { banks in Poland and some foreign } \\
\text { investors were encouraged to purchase } \\
\text { some of small ailing banks in order to } \\
\text { restructure them. }\end{array}$ \\
\hline Portugal & $\begin{array}{l}\text { External trade imbalances, high } \\
\text { foreign interest rates and high } \\
\text { government deficits from 1983- } \\
1985 \text {. }\end{array}$ & $\begin{array}{l}\text { The roots of the crisis were due } \\
\text { to external trade imbalances, } \\
\text { high foreign interest rates and } \\
\text { high government deficits. }\end{array}$ & $\begin{array}{l}\text { IMF's assistance to finance the } \\
\text { sovereign banks and stabilize the } \\
\text { economy, plans to cut back on public } \\
\text { investment, a rise in domestic interest } \\
\text { rates, coupled privatizations and labor } \\
\text { market reforms. }\end{array}$ \\
\hline & $\begin{array}{l}\text { The US subprime crisis hit the } \\
\text { Portuguese banking system's } \\
\text { access to funds in the } \\
\text { international wholesale markets } \\
\text { and caused significant losses in } \\
\text { securities and the financial asset } \\
\text { portfolio. Later, the Portuguese } \\
\text { sovereign debt crisis strained the } \\
\text { bank's liquidity situation in } \\
\text { terms of funding costs as well as } \\
\text { the capacity to access } \\
\text { international debt markets. } \\
\text { Mostly the domestic imbalance, } \\
\text { non-financial private sector } \\
\text { indebtedness, and the sovereign } \\
\text { debt crisis had an exaggerated } \\
\text { the impact of the crisis from } \\
\text { 2008-2015. }\end{array}$ & $\begin{array}{l}\text { Signs of distress in the banking } \\
\text { system were observed after the } \\
\text { nationalization of Banco } \\
\text { Português de Negócios. In late } \\
2008 \text {, the crisis was } \\
\text { significantly escalated due to } \\
\text { the Portuguese sovereign debt } \\
\text { crisis. }\end{array}$ & $\begin{array}{l}\text { In late } 2008, \text { the Portuguese } \\
\text { government preserved the stability of } \\
\text { the financial system by strengthening } \\
\text { the state of guarantees for bank } \\
\text { deposits. Headquartered credit } \\
\text { institutes had provided by voluntary } \\
\text { recapitalization plans and state } \\
\text { guarantees to address the securitized } \\
\text { debt by Portuguese banks. In April } \\
2011 \text {, Banco de Portugal was required } \\
\text { to maintain a minimum Tier } 1 \text { ratio over } \\
8 \% \text {. In May } 2012 \text {, the Economic and } \\
\text { Financial Assistance program was } \\
\text { established a better and stable financial } \\
\text { system and made structural adjustments } \\
\text { of the Portuguese economy. The eight } \\
\text { major Portuguese banking groups had } \\
\text { to generate medium term funding, } \\
\text { capital with minimum amount of } \\
\text { regulatory capital at all times. } \\
\text { Additionally, a program was designed } \\
\text { to validate the data on assets and } \\
\text { solvency assessment. Furthermore, it } \\
\text { had included changes in deposit } \\
\text { guarantees funds; a new regulation was } \\
\text { established for the minimum Core Tier } \\
1 \text { capital ratio of } 9 \% \text { at the end of } 2011 \\
\text { and then } 10 \% \text { from the end of } 2012 \\
\text { onwards. The solvency and } \\
\text { deleveraging assessment framework } \\
\text { was enacted under the Financial } \\
\text { Assistance Program; in October } 2011\end{array}$ \\
\hline
\end{tabular}




\begin{tabular}{|c|c|c|c|}
\hline & & & $\begin{array}{l}\text { according to specific risk profile for } \\
\text { each institution / banking group. }\end{array}$ \\
\hline \multirow[t]{2}{*}{ Romania } & External shock (1981-1989) & $\begin{array}{l}\text { The } 1977 \text { oil crisis and the } \\
\text { higher interest rates resulting } \\
\text { from the } 1982 \text { global debt crisis } \\
\text { caused a surge in the cost of the } \\
\text { external debt. In } 1981 \text {, the } \\
\text { Romanian debt had been } \\
\text { burdened by the rapid increase } \\
\text { of the FED interest rates during } \\
\text { the late } 1970 \text { s. By the end of } \\
\text { 1981, Romanian banks debt to } \\
\text { foreign banks was high, and the } \\
\text { IMF declined to waive the } \\
\text { stand-by loan without reaching } \\
\text { agreement with the foreign } \\
\text { banks, then an agreement was } \\
\text { signed in December } 1982 \text {. }\end{array}$ & $\begin{array}{l}\text { The Romanian government } \\
\text { implemented tougher measurements to } \\
\text { pay back the total amount of external } \\
\text { debt after deteriorating international } \\
\text { support. In 1988, the Ceaușescu } \\
\text { government declined contracting } \\
\text { further loans from the IMF and ended } \\
\text { its permanent dependence on Western } \\
\text { financing. }\end{array}$ \\
\hline & $\begin{array}{l}\text { Leverage and rapid credit } \\
\text { growth as early signs of crisis, } \\
\text { liberalization of the exchange } \\
\text { rate and liberalization process } \\
\text { for the goods with administered } \\
\text { prices from 1996-2000. }\end{array}$ & $\begin{array}{l}\text { Systematic errors in previous } \\
\text { years, taking risky policies by } \\
\text { offering high interest rates } \\
\text { (mostly on household deposits) } \\
\text { and lending credits to troubled } \\
\text { companies with poor financial } \\
\text { and economic conditions, or } \\
\text { practicing connected lending. } \\
\text { Consequently, banks were } \\
\text { unable to recover credits and } \\
\text { collect interest, causing a } \\
\text { steady decrease in profitability, } \\
\text { liquidity, and solvency ratios. } \\
\text { A very high non-performing } \\
\text { loan ratio (over } 20 \% \text { in } 1997- \\
\text { 1998 and 10\% in } 1996 \text { ), } \\
\text { combined with bankruptcy of } \\
\text { the largest domestic bank } \\
\text { (Bancorex held more than } 20 \% \\
\text { of the total assets) in } 1999 \text {. } \\
\text { Also, beginning in } 1996 \text {, many } \\
\text { banks faced financial } \\
\text { difficulties, such as Dacia Felix } \\
\text { Bank, Credit Bank, Columna, } \\
\text { Bankcoop and Bancorex } \\
\text { forcing them to stop payments } \\
\text { as the financial difficulties } \\
\text { persisted into } 1998 \text {. During the } \\
\text { liberalization period, the } \\
\text { exchange rate and the process } \\
\text { for goods with controlled prices } \\
\text { contributed to significant } \\
\text { currency depreciation and high } \\
\text { inflation. }\end{array}$ & $\begin{array}{l}\text { Bankruptcy legislation and National } \\
\text { Bank of Romania Act addressed by } \\
\text { banking system. In 1996, Dacia Felix } \\
\text { Bank and Credit Bank had to be } \\
\text { restructured or go into bankruptcy } \\
\text { according to legal action took by the } \\
\text { National Bank of Romania. In 1997, } \\
\text { banks had completed financial } \\
\text { corrective measures taken by the } \\
\text { NBR's Board of Directors. The central } \\
\text { bank cancelled the licenses of two } \\
\text { banks in 1997. Granted especial loans } \\
\text { to some sectors, off balance-sheet } \\
\text { commitments, credit due to } \\
\text { mismanagement decisions, etc. In } \\
\text { April 1997, the IMF agreed to a 13- } \\
\text { month stand-by credit to support the } \\
\text { Romanian government's economic } \\
\text { program. The National Bank of } \\
\text { Romania implemented a package of } \\
\text { bank purging measures to heal the } \\
\text { banking system as a whole in } 1999 \text {. }\end{array}$ \\
\hline & $\begin{array}{l}\text { Leverage and rapid credit } \\
\text { growth as early signs of crisis, } \\
\text { mismatches and market } \\
\text { illiquidity from } 2007-2010 .\end{array}$ & $\begin{array}{l}\text { The Romanian economy was } \\
\text { hit by speculative capital } \\
\text { outflows, while excessive } \\
\text { credit growth built up, high } \\
\text { NPL ratios and low } \\
\text { profitability. The Romanian } \\
\text { capital market acted in a similar } \\
\text { manner as its European } \\
\text { counterparts. Shortly } \\
\text { thereafter, the European } \\
\text { sovereign debt crisis led to a } \\
\text { rise in the CDS quotes after } \\
2011 .\end{array}$ & $\begin{array}{l}\text { Between September } 2008 \text { and June } \\
2012 \text {, the monetary authority lowered } \\
\text { the policy rate from } 10.25 \% \text { to } 5.25 \% \\
\text { to preserve adequate monetary } \\
\text { conditions for both credit demand and } \\
\text { supply. The goal was to contain } \\
\text { inflation and to spur sustainable } \\
\text { economic growth. }\end{array}$ \\
\hline Sweden & $\begin{array}{l}\text { The combination of inflation, } \\
\text { low real interest rates and }\end{array}$ & $\begin{array}{l}\text { This crisis was rooted in the } \\
\text { real estate bubble, excessive }\end{array}$ & $\begin{array}{l}\text { The Swedish Government issued a } \\
\text { "blanket guarantee" to cover the entire }\end{array}$ \\
\hline
\end{tabular}




\begin{tabular}{|c|c|c|c|}
\hline & $\begin{array}{l}\text { deregulation of the financial } \\
\text { markets triggered higher real } \\
\text { estate prices. Then, a quick drop } \\
\text { in real estate prices caused a } \\
\text { sharp increase of credit losses } \\
\text { from 1991-1997. }\end{array}$ & $\begin{array}{l}\text { lending to the commercial real } \\
\text { estate sector and aggravated by } \\
\text { the international slowdown. } \\
\text { The CRE bubble was caused by } \\
\text { de-regulation of bank lending. } \\
\text { However, in the mid 1980's, } \\
\text { there was a substantial increase } \\
\text { in bank lending while the real } \\
\text { estate prices declined, thus } \\
\text { banks suffered heavy losses. }\end{array}$ & $\begin{array}{l}\text { banking system in September } 1992 \text {. In } \\
\text { 1993, a governmental program was } \\
\text { introduced to restructure the failed } \\
\text { banks. The government injected capital } \\
\text { into banks, while the assets of failed } \\
\text { banks were divided into "good"-bank } \\
\text { and "bad"-bank parts. }\end{array}$ \\
\hline & $\begin{array}{l}\text { Mismatches and market } \\
\text { illiquidity caused the crisis. } \\
\text { Moreover, excessive credit } \\
\text { growth, loss of confidence and } \\
\text { financial problems in the } \\
\text { markets were also key elements } \\
\text { of this crisis. Fortunately, there } \\
\text { was not a severe level of credit } \\
\text { losses, hence "no credit crunch" } \\
\text { from 2008-2010. }\end{array}$ & $\begin{array}{l}\text { Even though the crisis was a } \\
\text { domestic issue, it was still an } \\
\text { external shock to areas with a } \\
\text { heavy dependence on short- } \\
\text { term international financing } \\
\text { and the growth of credit } \\
\text { exposures towards the Baltic } \\
\text { economies for two of the major } \\
\text { banks. }\end{array}$ & $\begin{array}{l}\text { A system of government guarantees } \\
\text { offered to the participated banks and } \\
\text { capital injections, however, it was } \\
\text { limited, and the deposit insurance } \\
\text { system covered higher amounts of } \\
\text { savings. Moreover, the Central bank } \\
\text { (the Riksbank) issued a range of } \\
\text { measures to provide liquidity, both in } \\
\text { SEK and in foreign currency, as well a } \\
\text { quick and sharp reduction of its interest } \\
\text { rate. }\end{array}$ \\
\hline \multirow[t]{2}{*}{ Slovenia } & 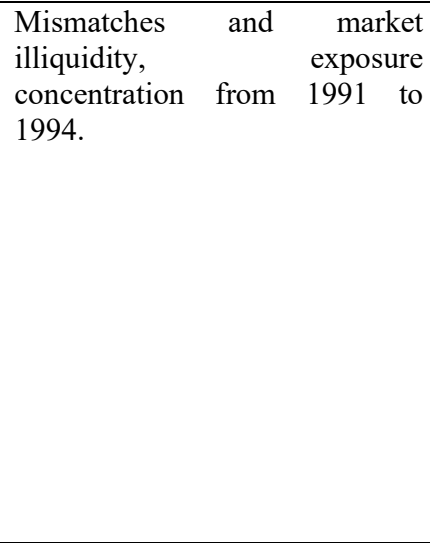 & $\begin{array}{l}\text { The Yugoslavian secession hit } \\
\text { the Slovene banks in three } \\
\text { channels: the liquidity } \\
\text { operations were not permitted } \\
\text { to Slovene banks; the Yugoslav } \\
\text { debtors became unenforceable; } \\
\text { Slovene non-financial } \\
\text { corporations (owners of the } \\
\text { most Slovene banks) had lost } \\
\text { access to the Yugoslav market, } \\
\text { resulting in impaired bank } \\
\text { assets through an increase of } \\
\text { loan delinquencies, as well } \\
\text { limiting bank recapitalization } \\
\text { by the non-government sector. }\end{array}$ & $\begin{array}{l}\text { Bank losses were written off against } \\
\text { capital; bank rehabilitation as } \\
\text { subordinated liabilities that were } \\
\text { government issued and held against } \\
\text { non-performing assets acquired and } \\
\text { paid for in the agency's own bonds. }\end{array}$ \\
\hline & $\begin{array}{l}\text { Leverage and rapid credit } \\
\text { growth as early signs of crisis: } \\
\text { The crisis was due to high } \\
\text { leverage, high LTD ratios and } \\
\text { decreasing lending standards } \\
\text { which caused a severe credit } \\
\text { crunch and the reduction of } \\
\text { credit availability especially to } \\
\text { over-indebted non-financial } \\
\text { sector. Mismatches and market } \\
\text { illiquidity: Slovenian banking } \\
\text { system relied mostly on short- } \\
\text { term funding that caused a sharp } \\
\text { decline after the outbreak of the } \\
\text { last crisis. } \\
\text { concentration: Exposure } \\
\text { economy relied on very specific } \\
\text { sectors and tightly connected to } \\
\text { the banks' ownership which } \\
\text { increased the concentration risk. } \\
\text { Misaligned incentives: The } \\
\text { management granted excessive } \\
\text { amounts of credit without proper } \\
\text { risk analysis from } 2009-2014 \text {. }\end{array}$ & $\begin{array}{l}\text { Banks failed to extend short } \\
\text { loans due to the freeze of the } \\
\text { wholesale financial markets, } \\
\text { thus they caused bad assets in } \\
\text { bank books, low loan loss } \\
\text { provisions and increased } \\
\text { capital requirements. During } \\
\text { the financial distress when } \\
\text { capital was difficult to raise, a } \\
\text { process of deleveraging began } \\
\text { while trying to reach the } \\
\text { required capital adequacy ratio. } \\
\text { Loans issued by the Slovenian } \\
\text { Banks were the prevailing } \\
\text { source of external finance for } \\
\text { the economy, so when their } \\
\text { lending rates were increased, } \\
\text { their ability to raise funds was } \\
\text { diminished. }\end{array}$ & $\begin{array}{l}\text { Banks' recapitalization such as NLB } \\
\text { d.d., NKBM d.d., Banka Celje d.d. , } \\
\text { Abanka Vipa d.d. as well as Factor } \\
\text { banka d.d. and Probanka d.d.; write- } \\
\text { down of subordinated instruments; } \\
\text { certain non-performing claims were } \\
\text { transferred from recapitalized banks to } \\
\text { the Bank Assets Management } \\
\text { Company (BAMC); BAMC acquired } \\
\text { assets paid with guaranteed bonds. The } \\
\text { last transfers of NPLs and last } \\
\text { recapitalization measures took place in } \\
\text { December 2014. }\end{array}$ \\
\hline Slovakia & $\begin{array}{l}\text { Misaligned incentives. Banks } \\
\text { that were to-big-to fail and } \\
\text { underlying problems, such as the } \\
\text { accumulation of bad loans due to } \\
\text { political pressure, the economic } \\
\text { structural and legal system after }\end{array}$ & $\begin{array}{l}\text { Started with the liquidity } \\
\text { problem of one of the banks in } \\
\text { December } 1997 . \text { In } 1998, \text { the } \\
\text { banking sector suffered losses } \\
\text { from non-performing loans } \\
\text { and increasing in NPL ratio } \\
\text { before the restructuralisation }\end{array}$ & $\begin{array}{l}\text { The National Central provided a } \\
\text { liquidity support for one bank by end of } \\
\text { 1997. Three largest banks were } \\
\text { recapitalized by the state and the } \\
\text { National Bank of Slovakia. Banks' bad } \\
\text { loans removed, loans granted to } \\
\text { insolvent companies were replaced }\end{array}$ \\
\hline
\end{tabular}




\begin{tabular}{|c|c|c|c|}
\hline & $\begin{array}{l}1989 \text { and also weak banks and } \\
\text { supervision from 1997-2002. }\end{array}$ & $\begin{array}{l}\text { of up to } 50 \% \text { in the case of } \\
\text { corporate loans. From the end } \\
\text { of } 1999 \text { to June } 2000 \text {, the loans } \\
\text { that had been granted to } \\
\text { insolvent corporates were } \\
\text { replaced by government bonds. }\end{array}$ & $\begin{array}{l}\text { with government bonds. Staged } \\
\text { restructuralisation process started and } \\
\text { banks' privatization was ended by } \\
\text { March } 2002 \text { as all three banks were } \\
\text { bought by foreign banking groups. }\end{array}$ \\
\hline \multirow[t]{3}{*}{$\begin{array}{l}\text { United } \\
\text { Kingdom }\end{array}$} & $\begin{array}{l}\text { From 1973-1977, leverage and } \\
\text { rapid credit growth as early signs } \\
\text { of crisis, mismatches in balance } \\
\text { sheets. In the early } 1970 \mathrm{~s} \text {, the } \\
\text { UK credit expansion as well as } \\
\text { the economy expanded rapidly } \\
\text { ("Barber boom"). The crisis } \\
\text { became visible as the liquidity } \\
\text { constraints in the money } \\
\text { markets. Some financial } \\
\text { institutions relied upon liquidity } \\
\text { for their operations; } \\
\text { sophisticated depositors revised } \\
\text { their exposure and further } \\
\text { affected the liquidity of } \\
\text { institutions. }\end{array}$ & $\begin{array}{l}\text { The crisis was caused by credit } \\
\text { expansion (property-related } \\
\text { assets). During the } \\
\text { depreciation of the sterling in } \\
\text { 1973, the BOE (Bank of } \\
\text { England) had to raise the } \\
\text { lending rate to support the } \\
\text { pound. Moreover, access to the } \\
\text { wholesale funding market was } \\
\text { hammered by special deposit } \\
\text { supplementary specided } \\
\text { scheme which generated } \\
\text { significant liquidity } \\
\text { constraints. Therefore, the } \\
\text { currency crisis indirectly } \\
\text { triggered the liquidity crisis, } \\
\text { however, the real problem was } \\
\text { in the banking sector. }\end{array}$ & $\begin{array}{l}\text { Several supporting measures and rescue } \\
\text { strategies were applied to a number of } \\
\text { troubled individual institutions. For } \\
\text { example, Bank of England assigned and } \\
\text { participated in "Lifeboat". }\end{array}$ \\
\hline & $\begin{array}{l}\text { Leverage and rapid credit } \\
\text { growth as early signs of crisis, } \\
\text { mismatches in balance sheets } \\
\text { from 1991-1994. }\end{array}$ & $\begin{array}{l}\text { In the European Rate } \\
\text { Mechanism (ERM) crisis, a fast } \\
\text { credit expansion related to } \\
\text { property assets was the trigger. } \\
\text { Without the support of the } \\
\text { authorities, many small } \\
\text { institutions had no access to } \\
\text { their funds at the Bank of } \\
\text { Credit and Commerce } \\
\text { International. The ERM } \\
\text { required a higher interest rate. } \\
\text { This aggravated the economic } \\
\text { slowdown and lowered } \\
\text { property prices. Next, the } \\
\text { unpredictable status of } \\
\text { financial institutions } \\
\text { constrained wholesale market } \\
\text { liquidity for SIB's from a } \\
\text { macroprudential perspective. }\end{array}$ & $\begin{array}{l}\text { Emergency liquidity support provided } \\
\text { to UK banks. }\end{array}$ \\
\hline & $\begin{array}{l}\text { 2007-present, leverage and rapid } \\
\text { credit growth as early signs of } \\
\text { crisis, mismatches in balance } \\
\text { sheet prior to the } 2008 \text { crisis. }\end{array}$ & $\begin{array}{l}\text { The instability was due to a } \\
\text { weak financial system that } \\
\text { perished during an extended } \\
\text { global credit boom; rapid } \\
\text { expansion of balance sheets; } \\
\text { uncertain liquidity and credit } \\
\text { quality; and poorly funding } \\
\text { structures. }\end{array}$ & $\begin{array}{l}\text { Bank recapitalization and special } \\
\text { liquidity schemes to swap temporarily } \\
\text { banks' high-quality mortgage-backed } \\
\text { besides other securities for UK } \\
\text { Treasury Bills in 2008. Additional } \\
\text { supportive measures from the Bank of } \\
\text { England, ECB, Federal Reserve, Swiss } \\
\text { National and Canadian banks to ease } \\
\text { the pressures on short-term funding } \\
\text { markets (FSRs in July 2009). }\end{array}$ \\
\hline
\end{tabular}

Source: completed by author.

The outcomes of this research are (Rsource: own study):

\begin{tabular}{|c|l|l|l|}
\hline 1. & $\begin{array}{l}\text { Research question } \\
\text { Determine whether it is plausible to only } \\
\text { focus on the interaction between profitability } \\
\text { and macroeconomic factors for future } \\
\text { examinations of European banks soundness. }\end{array}$ & Inconclusive & $\begin{array}{l}\text { Reasons } \\
\text { 1. }\end{array}$ \\
$\begin{array}{l}\text { Without supervision, taking into } \\
\text { consideration the rating systems outlooks } \\
\text { and regulatory (such as Basel III), it is } \\
\text { difficult to predict the soundness for the } \\
\text { long run. Relying on the Moody's rating } \\
\text { outlook and other supervisory institutes } \\
\text { may provide a future indication. }\end{array}$ \\
\hline
\end{tabular}

Source: completed by author. 


\section{Conclusion}

During the crises, European banks heavily addressed the macro profile as well as government and central bank interventions, emergency liquidation, financial stability programs, reconstructing reforms, strength of the supervisors and monetary policies. I conclude that during crises, lending in foreign currency, fiscal discipline, GDP, inflation, high interest rates in foreign currency deposit and loans escalated the problem. With reference to my previous article, any new methodology has to consider the external, industry and internal determinants of profitability in the equation of bank soundness while setting minimum capital requirements, liquidity and bail-in-able liabilities. Therefore, we should strive to improve the existing methodologies and re-regulatory supervision. However, most scholars have focused on the impact of the macroeconomic environment on bank profitability using inflation rates, GDP, and interest rates. Moreover, macro profile, regulatory and supervision, profitability and rating system are also four significant variables in evaluating bank soundness. On the microeconomic level, there is always a possibility to introduce new variables due to new regulatory, or banking supervisory institutions regulations, while at macroeconomic level, the ability to predict these factors positively effects bank soundness. In summary, macroeconomic adjustments were called upon during the crises due to the decline of capital adequacy and deterioration of asset quality as well as losses in both foreign exchange and foreign currency liquidity.

The evidence shown affirms the following statement "is it possible to predict the financial distress in European banks based on systematic financial information and reports, rating system, Basel minimum capital requirements and stress tests, ..., etc." to absorb any financial crises similar to the collapse of Lehman Brothers, US subprime crisis, financial crisis (2008) and the Asian financial crisis, if there was a prevention mechanism to halt the contagion mechanism. Under these backgrounds, many banking sectors, financial analytics, academicians tended to be against a collaborative effort to build a unified predictive model to ensure the soundness of banks. Therefore, any framework to assess the financial stability must address three main issues: the risks and vulnerabilities of banks individually and world-wide, the type of risks that cause the vulnerabilities and the contagion mechanisms that magnify the impact of the crisis. The next Figure may summarize the most foundations of the topology of Soundness of banks.

The Topology of Soundness of Bank

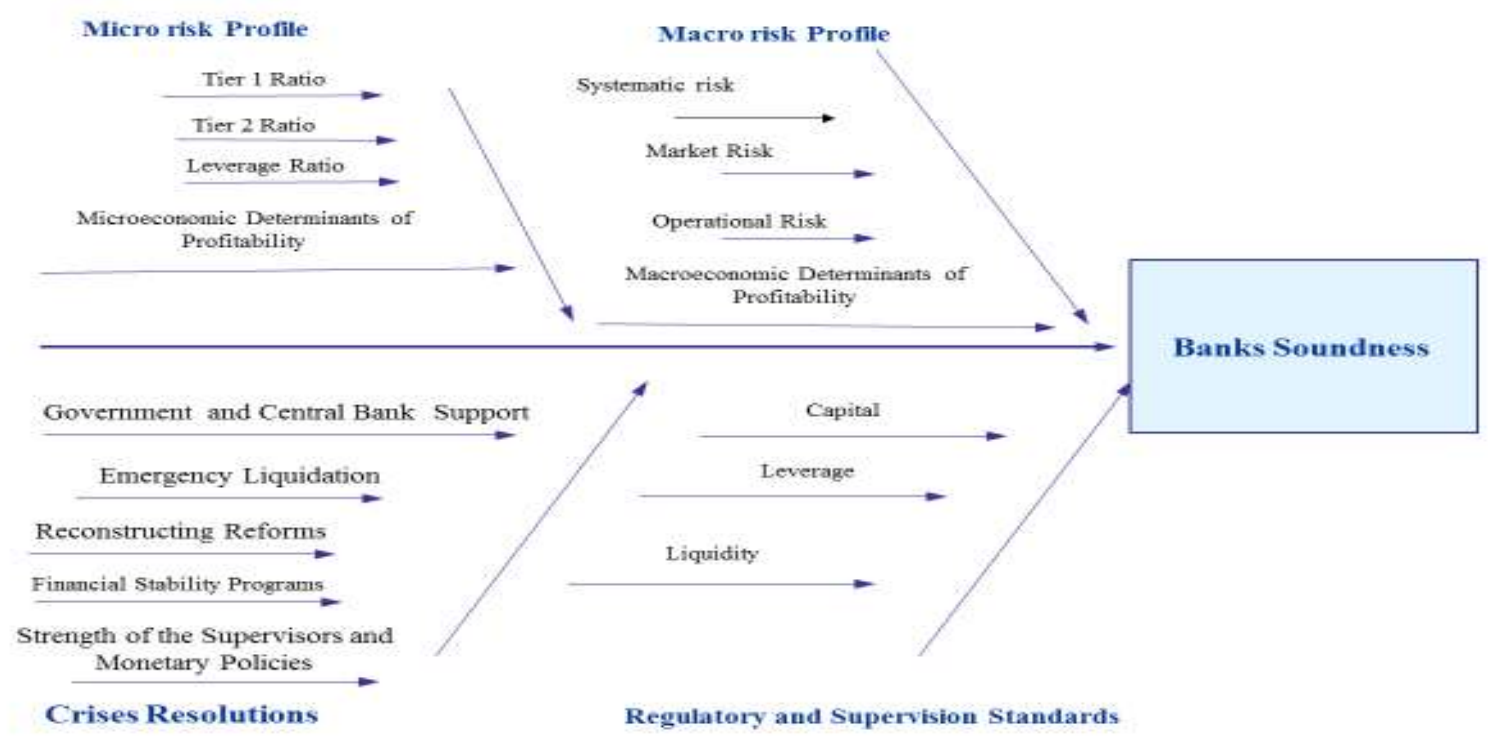

Figure 4: The Topology of Soundness of Banks. Resource: Own study.

Source: completed by author. 
Appendix A

Table 3: The most repeated macroeconomic determinants in selected Empirical Studies

\begin{tabular}{|c|c|c|c|c|}
\hline Name of articles & $\begin{array}{l}\text { Type of } \\
\text { studies }\end{array}$ & Journal & Variables & Methodology \\
\hline $\begin{array}{l}\text { 1. Determinants of Bank } \\
\text { Profitability in } \\
\text { Ukraine. }\end{array}$ & $\begin{array}{l}\text { Empirical } \\
\text { Studies }\end{array}$ & $\begin{array}{l}\text { Undergraduate } \\
\text { Economic } \\
\text { Review }\end{array}$ & $\begin{array}{ll}\text { 1. } & \text { GDP Growth } \\
\text { 2. Inflation } \\
\text { 3. Exchange Rate } \\
\text { 4. } \\
\text { Concentration }\end{array}$ & $\begin{array}{l}\text { A linear model } \\
\text { of profitability }\end{array}$ \\
\hline 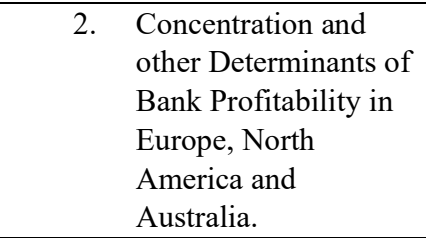 & $\begin{array}{l}\text { Empirical } \\
\text { Studies }\end{array}$ & $\begin{array}{l}\text { Journal of } \\
\text { Banking \& } \\
\text { Finance }\end{array}$ & $\begin{array}{ll}\text { 1. } & \text { Concentration } \\
\text { 2. } & \text { Market Growth } \\
\text { 3. } & \text { Inflation }\end{array}$ & $\begin{array}{l}\text { A linear model } \\
\text { of profitability }\end{array}$ \\
\hline 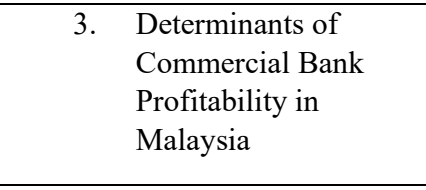 & $\begin{array}{l}\text { Empirical } \\
\text { Studies }\end{array}$ & $\begin{array}{l}\text { Journal of } \\
\text { Money, Credit, } \\
\text { and Banking }\end{array}$ & $\begin{array}{ll}\text { 1. } & \text { Inflation } \\
\text { 2. } & \text { Market Growth } \\
\text { 3. } & \text { Market Interest } \\
\text { 4. } & \text { Market Share } \\
\text { 5. } & \text { Regulation } \\
\end{array}$ & $\begin{array}{l}\text { A linear model } \\
\text { of profitability }\end{array}$ \\
\hline $\begin{array}{l}\text { 4. What Explains the } \\
\text { Low Profitability of } \\
\text { Chinese Banks? }\end{array}$ & $\begin{array}{l}\text { Empirical } \\
\text { Studies }\end{array}$ & $\begin{array}{l}\text { Journal of } \\
\text { Banking \& } \\
\text { Finance }\end{array}$ & $\begin{array}{ll}\text { 1. } & \text { Real GDP growth } \\
\text { 2. } & \text { Inflation } \\
\text { 3. } & \text { Interest Rate } \\
\text { 4. } & \text { Maximum spread between } \\
& \text { loan and deposit rates } \\
\text { 5. } & \text { Volatility of interest rates } \\
\text { 6. } & \text { Concentration } \\
\text { 7. } & \text { System Credit Growth } \\
\text { 8. } & \text { Interest Rate } \\
\end{array}$ & $\begin{array}{l}\text { Regression } \\
\text { Model }\end{array}$ \\
\hline $\begin{array}{l}\text { Factors influencing } \\
\text { the profitability of } \\
\text { domestic and foreign } \\
\text { commercial banks in } \\
\text { the European Union. }\end{array}$ & $\begin{array}{l}\text { Empirical } \\
\text { Studies }\end{array}$ & $\begin{array}{l}\text { Research in } \\
\text { International } \\
\text { Business and } \\
\text { Finance }\end{array}$ & $\begin{array}{l}\text { 1. Inflation } \\
\text { 2. GDP Growth } \\
\text { 3. Concentration } \\
\text { 4. The ratio total assets of the } \\
\text { deposit money banks divided } \\
\text { by the GDP. } \\
\text { 5. The ratio stock market } \\
\text { capitalization to total assets } \\
\text { of the deposit money banks. } \\
\text { 6. The ratio stock market } \\
\text { capitalization to GDP. }\end{array}$ & $\begin{array}{l}\text { Regression } \\
\text { Model }\end{array}$ \\
\hline $\begin{array}{l}\text { 6. } \\
\text { peterminants of bank } \\
\text { developing economy: } \\
\text { empirical evidence } \\
\text { from the Philippines }\end{array}$ & $\begin{array}{l}\text { Empirical } \\
\text { Studies }\end{array}$ & $\begin{array}{l}\text { Asian Academy } \\
\text { of Management } \\
\text { Journal of } \\
\text { Accounting \& } \\
\text { Finance }\end{array}$ & $\begin{array}{ll}\text { 1. } & \text { GDP Growth Rate } \\
\text { 2. } & \text { Inflation } \\
\text { 3. } & \text { Money supply growth } \\
\text { 4. } & \text { The ratio of stock market } \\
\text { capitalization. The variable } \\
\text { serves as a proxy of financial } \\
\text { development }\end{array}$ & $\begin{array}{l}\text { Linear } \\
\text { Regression } \\
\text { Model }\end{array}$ \\
\hline $\begin{array}{l}\text { 7. Determinants of bank } \\
\text { profitability before } \\
\text { and during the crisis: } \\
\text { Evidence from } \\
\text { Switzerland }\end{array}$ & $\begin{array}{l}\text { Empirical } \\
\text { Studies }\end{array}$ & $\begin{array}{l}\text { Journal of } \\
\text { International } \\
\text { Financial } \\
\text { Markets, } \\
\text { Institutions and } \\
\text { Money } \\
\end{array}$ & $\begin{array}{ll}\text { 1. } & \text { Effective Tax Rate } \\
\text { 2. } & \text { Real GDP Growth } \\
\text { 3. } & \text { Interest Rates } \\
\text { 4. } & \text { Concentration }\end{array}$ & A linear model \\
\hline $\begin{array}{ll}8 . & \text { Determinants of } \\
\text { banks' profitability: } \\
\text { evidence from EU } 27 \\
\text { banking systems }\end{array}$ & $\begin{array}{l}\text { Empirical } \\
\text { Studies }\end{array}$ & $\begin{array}{l}\text { Procedia } \\
\text { Economics and } \\
\text { Finance } 20 \\
(2015)\end{array}$ & $\begin{array}{ll}\text { 1. } & \text { Inflation } \\
\text { 2. } & \text { GDP Growth }\end{array}$ & $\begin{array}{l}\text { A linear model } \\
\text { of profitability }\end{array}$ \\
\hline $\begin{array}{ll}\text { 9. } & \text { Banks' Profitability in } \\
\text { Selected Central and } \\
\text { Eastern European } \\
\text { Countries }\end{array}$ & $\begin{array}{l}\text { Empirical } \\
\text { Studies }\end{array}$ & $\begin{array}{l}\text { Procedia } \\
\text { Economics and } \\
\text { Finance } 16 \\
(2014)\end{array}$ & $\begin{array}{ll}\text { 1. } & \text { Inflation } \\
\text { 2. } & \text { GDP Growth } \\
\text { 3. } & \text { Crisis } \\
\text { 4. } & \text { Concentration } \\
\end{array}$ & $\begin{array}{l}\text { A linear model } \\
\text { of profitability }\end{array}$ \\
\hline $\begin{array}{l}\text { 10. } \\
\text { Bank-specific, } \\
\text { industry-specific and } \\
\text { macroeconomic } \\
\text { determinants of bank } \\
\text { profitability } \\
\end{array}$ & $\begin{array}{l}\text { Empirical } \\
\text { Studies }\end{array}$ & $\begin{array}{l}\text { Journal } \\
\text { ofInternational } \\
\text { Financial } \\
\text { Markets, }\end{array}$ & $\begin{array}{ll}\text { 1. } & \text { Inflation } \\
\text { 2. } & \text { Cyclical Output } \\
\text { 3. } & \text { Concentration }\end{array}$ & $\begin{array}{l}\text { A linear model } \\
\text { of profitability }\end{array}$ \\
\hline
\end{tabular}




\begin{tabular}{|c|c|c|c|c|c|}
\hline & & & $\begin{array}{l}\text { Institutions and } \\
\text { Money }\end{array}$ & & \\
\hline & $\begin{array}{l}\text { Bank Specific and } \\
\text { Macroeconomic } \\
\text { Determinants of } \\
\text { Commercial Bank } \\
\text { Profitability: } \\
\text { Empirical Evidence } \\
\text { from Turkey }\end{array}$ & $\begin{array}{l}\text { Empirical } \\
\text { Studies }\end{array}$ & $\begin{array}{l}\text { Business and } \\
\text { Economics } \\
\text { Research } \\
\text { Journal }\end{array}$ & $\begin{array}{ll}\text { 1. } & \text { Annual Real GDP Growth } \\
& \text { Rate } \\
\text { 2. } & \text { Inflation Rate } \\
\text { 3. } & \text { Real Interest Rate }\end{array}$ & $\begin{array}{l}\text { A regression } \\
\text { model }\end{array}$ \\
\hline & $\begin{array}{l}\text { Profitability of the } \\
\text { Korean banking } \\
\text { sector: Panel evidence } \\
\text { on bank-specific and } \\
\text { macroeconomic } \\
\text { determinants. }\end{array}$ & $\begin{array}{l}\text { Empirical } \\
\text { Studies }\end{array}$ & $\begin{array}{l}\text { Journal of } \\
\text { Economics and } \\
\text { Management }\end{array}$ & $\begin{array}{ll}\text { 1. } & \text { GDP } \\
\text { 2. } & \text { Inflation } \\
\text { 3. } & \text { Concentration } \\
\text { 4. } & \text { The ratio of stock market } \\
& \text { capitalization }\end{array}$ & $\begin{array}{l}\text { A regression } \\
\text { model }\end{array}$ \\
\hline & $\begin{array}{l}\text { Financial structure } \\
\text { and bank profitability. }\end{array}$ & $\begin{array}{l}\text { Empirical } \\
\text { Studies }\end{array}$ & $\begin{array}{l}\text { Journal of } \\
\text { Economics and } \\
\text { Management }\end{array}$ & $\begin{array}{ll}\text { 1. } & \text { Annual Real GDP Growth } \\
& \text { Rate } \\
\text { 2. } & \text { Inflation } \\
\text { 3. } & \text { Tax Rate } \\
\end{array}$ & $\begin{array}{l}\text { A regression } \\
\text { model }\end{array}$ \\
\hline & $\begin{array}{l}\text { Determinants of } \\
\text { profitability of } \\
\text { domestic UK } \\
\text { commercial banks: } \\
\text { panel evidence from } \\
\text { the period } 1995-2002\end{array}$ & $\begin{array}{l}\text { Empirical } \\
\text { Studies }\end{array}$ & $\begin{array}{l}\text { Money Macro } \\
\text { and Finance } \\
\text { (MMF) } \\
\text { Research } \\
\text { Group } \\
\text { Conference }\end{array}$ & $\begin{array}{l}\text { 1. The Rate of GDP Growth } \\
\text { 2. Inflation } \\
\text { 3. Concentration } \\
\text { 4. The ratio of stock market } \\
\text { capitalization to total assets } \\
\text { of the deposit money banks. } \\
\text { This variable serves as a } \\
\text { proxy of financial } \\
\text { development as well as a } \\
\text { measure of the size of } \\
\text { financial market and the } \\
\text { relationship between bank } \\
\text { and market financing. } \\
\end{array}$ & $\begin{array}{l}\text { A regression } \\
\text { model }\end{array}$ \\
\hline & $\begin{array}{l}\text { What determines the } \\
\text { profitability of banks? } \\
\text { Evidence from Spain }\end{array}$ & $\begin{array}{l}\text { Empirical } \\
\text { Studies }\end{array}$ & $\begin{array}{l}\text { Accounting \& } \\
\text { Finance }\end{array}$ & $\begin{array}{ll}\text { 1. } & \text { Concentration } \\
\text { 2. Annual Real GDP Growth } \\
\text { Rate } \\
\text { 3. Inflation } \\
\text { 4. Interest Rates } \\
\end{array}$ & $\begin{array}{l}\text { A regression } \\
\text { model }\end{array}$ \\
\hline & $\begin{array}{l}\text { Bank liquidity and its } \\
\text { determinants in } \\
\text { Romania }\end{array}$ & $\begin{array}{l}\text { Empirical } \\
\text { Studies }\end{array}$ & $\begin{array}{l}\text { Procedia } \\
\text { Economics and } \\
\text { Finance }\end{array}$ & $\begin{array}{ll}\text { 1. } & \text { Interest Rate } \\
\text { 2. } & \text { Credit Risk Rate } \\
\text { 3. } & \text { Inflation } \\
\text { 4. } & \text { GDP Real Growth Rate } \\
\text { 5. } & \text { Unemployment } \\
\end{array}$ & $\begin{array}{l}\text { A multivariable } \\
\text { regression model } \\
\text { and Z-score }\end{array}$ \\
\hline & $\begin{array}{l}\text { Profitability } \\
\text { Determinants of the } \\
\text { Macedonian Banking } \\
\text { Sector in Changing } \\
\text { Environment }\end{array}$ & $\begin{array}{l}\text { Empirical } \\
\text { Studies }\end{array}$ & $\begin{array}{l}\text { Procedia- } \\
\text { Social and } \\
\text { Behavioral } \\
\text { Sciences } 44 \\
(2012)\end{array}$ & $\begin{array}{ll}\text { 1. } & \text { GDP Growth Rate } \\
\text { 2. } & \text { Concentration } \\
\text { 3. } & \text { EBRD index } \\
\text { 4. } & \text { Inflation }\end{array}$ & $\begin{array}{l}\text { A regression } \\
\text { model }\end{array}$ \\
\hline & $\begin{array}{l}\text { Profitability of } \\
\text { foreign and domestic } \\
\text { banks in Central and } \\
\text { Eastern Europe: does } \\
\text { the mode of entry } \\
\text { matter? }\end{array}$ & $\begin{array}{l}\text { Empirical } \\
\text { Studies }\end{array}$ & & $\begin{array}{ll}\text { 1. } & \text { Concentration } \\
\text { 2. } & \text { Inflation } \\
\text { 3. } & \text { Host Interest Rate } \\
\text { 4. } & \text { Host GDP }\end{array}$ & $\begin{array}{l}\text { A logit model } \\
\text { for dependent } \\
\text { variables and } \\
\text { regression model }\end{array}$ \\
\hline & $\begin{array}{l}\text { Determinants of bank } \\
\text { Profitability in the } \\
\text { South Eastern } \\
\text { European region }\end{array}$ & $\begin{array}{l}\text { Empirical } \\
\text { Studies }\end{array}$ & MPRA Paper & $\begin{array}{ll}\text { 1. } & \text { Inflation } \\
\text { 2. } & \text { Real per Capita Income }\end{array}$ & $\begin{array}{l}\text { A regression } \\
\text { model }\end{array}$ \\
\hline & $\begin{array}{l}\text { Are Foreign Banks } \\
\text { more Profitable than } \\
\text { Domestic Banks? } \\
\text { Home- and Host- } \\
\text { Country Effects of } \\
\text { Banking Market } \\
\text { Structure, } \\
\text { Governance, and } \\
\text { Supervision }\end{array}$ & $\begin{array}{l}\text { Empirical } \\
\text { Studies }\end{array}$ & $\begin{array}{l}\text { Journal of } \\
\text { Banking \& } \\
\text { Finance }\end{array}$ & $\begin{array}{ll}\text { 1. } & \text { GDP Growth } \\
\text { 2. } & \text { Inflation Rate } \\
\text { 3. } & \text { Real Interest Rate }\end{array}$ & $\begin{array}{l}\text { Panzar-Rosse H- } \\
\text { statistic to } \\
\text { measure } \\
\text { Banking Market } \\
\text { Structure and } \\
\text { regression model }\end{array}$ \\
\hline
\end{tabular}




\begin{tabular}{|c|c|c|c|c|c|}
\hline & $\begin{array}{l}\text { Bank-specific, } \\
\text { industry-specific and } \\
\text { macroeconomic } \\
\text { determinants of bank }\end{array}$ & $\begin{array}{l}\text { Empirical } \\
\text { Studies }\end{array}$ & & $\begin{array}{ll}\text { 1. } & \text { Inflation } \\
\text { 2. } & \text { Cyclical Output }\end{array}$ & $\begin{array}{l}\text { A regression } \\
\text { model }\end{array}$ \\
\hline 22. & $\begin{array}{l}\text { The determinants of } \\
\text { banks' profits in } \\
\text { Greece during the } \\
\text { period of EU } \\
\text { financial integration }\end{array}$ & $\begin{array}{l}\text { Empirical } \\
\text { Studies }\end{array}$ & $\begin{array}{l}\text { Managerial } \\
\text { Finance }\end{array}$ & $\begin{array}{l}\text { 1. GDP Growth } \\
\text { 2. Inflation } \\
\text { 3. The growth of the money } \\
\text { supply as measured by } \\
\text { currency circulation } \\
\text { The ratio stock market } \\
\text { capitalization to total assets } \\
\text { of the deposit money banks. } \\
\text { The ratio total assets of the } \\
\text { deposit money banks divided } \\
\text { by the GDP } \\
\text { 6. Concentration }\end{array}$ & $\begin{array}{l}\text { A regression } \\
\text { model }\end{array}$ \\
\hline 23. & $\begin{array}{l}\text { How Accurately Can } \\
\text { Z-score Predict Bank } \\
\text { Failure? }\end{array}$ & $\begin{array}{l}\text { Empirical } \\
\text { Studies }\end{array}$ & & $\begin{array}{ll}\text { 1. } & \text { GDP Growth } \\
\text { 2. } & \text { Inflation } \\
\text { 3. } & \text { Concentration } \\
\end{array}$ & $\begin{array}{l}\text { Z-Score } \\
\text { Methodology }\end{array}$ \\
\hline & $\begin{array}{l}\text { Consolidation in } \\
\text { banking and financial } \\
\text { stability in Europe: } \\
\text { Empirical evidence }\end{array}$ & $\begin{array}{l}\text { Empirical } \\
\text { Studies }\end{array}$ & $\begin{array}{l}\text { Journal of } \\
\text { Banking \& } \\
\text { Finance }\end{array}$ & $\begin{array}{ll}\text { 1. } & \text { Concentration } \\
\text { 2. } & \text { GDP per Capita } \\
\text { 3. } & \text { Real GDP Growth } \\
\text { 4. } & \text { Inflation } \\
\text { 5. } & \text { Real Interest Rate } \\
\text { 6. } & \text { Credit Growth }\end{array}$ & Z-Score \\
\hline & $\begin{array}{l}\text { Competition, } \\
\text { Efficiency, and } \\
\text { Stability in Banking. }\end{array}$ & $\begin{array}{l}\text { Empirical } \\
\text { Studies }\end{array}$ & $\begin{array}{l}\text { Financial } \\
\text { Management }\end{array}$ & $\begin{array}{ll}\text { 1. } & \text { GDP per Capita } \\
\text { 2. } & \text { Concentration }\end{array}$ & $\begin{array}{l}\text { Bonne Model, Z- } \\
\text { Score } \\
\text { Methodology }\end{array}$ \\
\hline 26. & $\begin{array}{l}\text { The Main } \\
\text { Determinants of } \\
\text { Bank's Stability. } \\
\text { Evidence from } \\
\text { Romanian Banking } \\
\text { Sector }\end{array}$ & $\begin{array}{l}\text { Empirical } \\
\text { Studies }\end{array}$ & $\begin{array}{l}\text { Procedia } \\
\text { Economics and } \\
\text { Finance }\end{array}$ & $\begin{array}{ll}\text { 1. } & \text { Inflation Rate } \\
\text { 2. } & \text { GDP Growth Rate }\end{array}$ & Z-Score Model \\
\hline 27. & $\begin{array}{l}\text { Does market structure } \\
\text { matter on banks' } \\
\text { profitability and } \\
\text { stability? Emerging } \\
\text { vs. advanced } \\
\text { economies. }\end{array}$ & $\begin{array}{l}\text { Empirical } \\
\text { Studies }\end{array}$ & $\begin{array}{l}\text { Journal of } \\
\text { Banking \& } \\
\text { Finance }\end{array}$ & $\begin{array}{ll}\text { 1. } & \text { Real GDP Growth } \\
\text { 2. Stock market turnover ratio } \\
\text { 3. Inflation } \\
\text { 4. Concentration }\end{array}$ & $\begin{array}{l}\text { Z-Score } \\
\text { Methodology } \\
\text { and regression } \\
\text { model }\end{array}$ \\
\hline 28. & $\begin{array}{l}\text { Basel Core Principles } \\
\text { and bank soundness: } \\
\text { Does compliance } \\
\text { matter? }\end{array}$ & $\begin{array}{l}\text { Empirical } \\
\text { Studies }\end{array}$ & $\begin{array}{l}\text { Journal of } \\
\text { Financial } \\
\text { Stability }\end{array}$ & $\begin{array}{ll}\text { 1. } & \text { GDP Growth } \\
\text { 2. } & \text { Inflation } \\
\text { 3. } & \text { Exchange Rate }\end{array}$ & $\begin{array}{l}\text { Z-Score } \\
\text { Methodology } \\
\text { and regression } \\
\text { model }\end{array}$ \\
\hline & $\begin{array}{l}\text { Bank Safety and } \\
\text { Soundness and the } \\
\text { Structure of Bank } \\
\text { Supervision: A Cross } \\
\text { Country Analysis } \\
\end{array}$ & $\begin{array}{l}\text { Empirical } \\
\text { Studies }\end{array}$ & & $\begin{array}{ll}\text { 1. } & \text { Concentration } \\
\text { 2. } & \text { GDP per Capita } \\
\text { 3. } & \text { Average Rate of Real GDP } \\
& \text { Growth }\end{array}$ & $\begin{array}{l}\text { CAMEL } \\
\text { variables as well } \\
\text { as regression } \\
\text { model }\end{array}$ \\
\hline & $\begin{array}{l}\text { Banking on the } \\
\text { principles: } \\
\text { Compliance with } \\
\text { Basel Core Principles } \\
\text { and Bank Soundness. }\end{array}$ & & $\begin{array}{l}\text { The World } \\
\text { Bank }\end{array}$ & $\begin{array}{ll}\text { 1. } & \text { BCP Index } \\
\text { 2. } & \text { Rule of Law } \\
\text { 3. } & \text { GDP per Capita } \\
\text { 4. } & \text { Depreciation } \\
\text { 5. } & \text { Growth } \\
\text { 6. } & \text { Inflation } \\
\text { 7. } & \text { Inflation Volatility }\end{array}$ & $\begin{array}{l}\text { Z-Score, } \\
\text { Moody's Rating, } \\
\text { and Regression } \\
\text { model }\end{array}$ \\
\hline
\end{tabular}

\section{Source: Own study.}

\section{References}

1. Abreu, M., \& Mendes, V. (2001, May). Commercial bank interest margins and profitability: evidence for some EU countries. In Pan-European Conference Jointly Organised by the IEFS-UK \& University of Macedonia Economic \& Social Sciences, Thessaloniki, Greece, May, 17-20.

2. Albert Amponsah Addae, Michael Nyarko-Baasi, Michael Lawer Tetteh (2014). Effect of Exchange Rate Movements on Ghanaian Banks, Journal of Finance and Accounting. (2)3, 62-71. doi: 10.11648/j.jfa.20140203.15 
3. Adler, M., \& Dumas, B. (1980). The Exposure of Long-Term Foreign Currency Bonds. Journal of Financial and Quantitative Analysis, 15(4), 973-994. DOI: 10.2307/2330573.

4. Ally, Z. (2014). Determinants of Banks' Profitability in a Developing Economy: Empirical Evidence from Tanzania.

5. Agoraki, M.-E. K., Delis, M. D., \& Pasiouras, F. (2011). Regulations, competition and bank risk-taking in transition countries. Journal of Financial Stability, 7(1), 38-48. doi: 10.1016/j.jfs.2009.08.002

6. Albertazzi, U., \& Gambacorta, L. (2009). Bank Profitability and the Business Cycle. Journal of Financial Stability, 5(4), 393-409. doi: 10.1016/j.jfs.2008.10.002.

7. Alexiou, C., \& Sofoklis, V. (2009). Determinants of Bank Profitability: Evidence from the Greek Banking Sector. Ekonomski Anali/Economic Annals, 54(182), 93-118. doi:10.2298/eka0982093a

8. Anbar, A., \& Alper, D. (2011). Bank Specific and Macroeconomic Determinants of Commercial Bank Profitability: Empirical Evidence from Turkey. Business and Economics Research Journal, 2(2), 139-152.

9. Athanasoglou, P. P., Brissimis, S. N., \& Delis, M. D. (2008). Bank-Specific, Industry-Specific and Macroeconomic Determinants of Bank Profitability. Journal of international financial Markets, Institutions and Money, 18(2), 121-136. doi: 10.1016/j.intfin.2006.07.001.

10. Athanasoglou, P., Delis, M., \& Staikouras, C. (2006). Determinants of Bank Profitability in the South Eastern European Region. Retrieved from: https://mpra.ub.uni-muenchen.de/id/eprint/10274.

11. Barth, J. R., Dopico, L. G., Nolle, D. E., \& Wilcox, J. A. (2002). Bank Safety and Soundness and the Structure of Bank Supervision: A Cross-Country Analysis. International Review of Finance, 3(3-4), 163188. doi:10.1111/j.1369-412x.2002. 00037.x

12. Berger, A. N., \& Humphrey, D. B. (1997). Efficiency of financial institutions: International survey and directions for future research. European Journal of Operational Research, 98(2), 175-212. doi:10.1016/s0377-2217(96)00342-6

13. Berger, A. N., Klapper, L. F., \& Turk-Ariss, R. (2009). Bank Competition and Financial Stability. Journal of Financial Services Research, 35(2), 99-118. doi:10.1007/s10693-008-0050-7

14. Bikker, J. A., \& Hu, H. (2002). Cyclical Patterns in Profits, Provisioning and Lending of Banks. De Nederlandsche Bank.

15. Bolt, W., de Haan, L., Hoeberichts, M., van Oordt, M. R. C., \& Swank, J. (2012). Bank Profitability during Recessions. Journal of Banking \& Finance, 36(9), 2552-2564. doi: 10.1016/j.jbankfin.2012.05.011

16. Bourke, P. (1989). Concentration and other Determinants of Bank Profitability in Europe, North America and Australia. Journal of Banking \& Finance, 13(1), 65-79. doi:10.1016/0378-4266(89)90020-4.

17. Calza, A., \& Sousa, J. (2006). Output and Inflation Responses to Credit Shocks: Are There Threshold Effects in the Euro Area? Studies in Nonlinear Dynamics \& Econometrics, 10(2). doi:10.2202/15583708.1253

18. Căpraru, B., \& Ihnatov, I. (2014). Banks' Profitability in Selected Central and Eastern European Countries. Procedia Economics and Finance, 16, 587-591. doi:10.1016/s2212-5671(14)00844-2

19. Chen, S. H., \& Liao, C. C. (2011). Are Foreign Banks more Profitable than Domestic Banks? Home-and Host-Country Effects of Banking Market Structure, Governance, and Supervision. Journal of Banking \& Finance. doi: 10.1016/j.jbankfin.2010.11.006

20. Chiaramonte, L., Croci, E., \& Poli, F. (2015). Should We Trust the Z-score? Evidence from the European Banking Industry. Global Finance Journal, 28, 111-131. doi: 10.1016/j.gfj.2015.02.002

21. Chiaramonte, L., Liu, F. H., Poli, F., \& Zhou, M. (2016). How Accurately Can Z-score Predict Bank Failure? Financial Markets, Institutions \& Instruments, 25(5), 333-360. doi:10.1111/fmii.12077.

22. Claeys, S., \& Vander Vennet, R. (2008). Determinants of Bank Interest Margins in Central and Eastern Europe: A comparison with the West. Economic Systems, 32(2), 197-216. doi: 10.1016/j.ecosys.2007.04.001

23. Curak, M., Poposki, K., \& Pepur, S. (2012). Profitability Determinants of the Macedonian Banking Sector in Changing Environment. Procedia - Social and Behavioral Sciences, 44, 406-416. doi: 10.1016/j.sbspro.2012.05.045.

24. Chamberlain, S., Howe, J. S., \& Popper, H. (1997). The Exchange Rate Exposure of US and Japanese Banking institutions. Journal of banking \& finance, 21(6), 871-892. doi:10.1016/s0378-4266(97)00002-2.

25. Combey, A., \& Togbenou, A. (2017). The Bank Sector Performance and Macroeconomics Environment: Empirical Evidence in Togo. International Journal of Economics and Finance, 9(2), 180. doi:10.5539/ijef. v9n2p180 
26. Dang, U. (2011). The CAMEL Rating System in Banking Supervision. A case Study.

27. Davydenko, Antonina (2010). Determinants of Bank Profitability in Ukraine, Undergraduate Economic Review, 7(1), Article 2. Available at: http://digitalcommons.iwu.edu/uer/vol7/iss1/2

28. De Guevara, J. F., \& Maudos, J. (2004). Measuring welfare loss of market power: an application to European banks. Applied Economics Letters, 11(13), 833-836. doi:10.1080/1350485042000263908

29. Demirguc-Kunt, A., \& Detragiache, E. (2000). Monitoring Banking Sector Fragility: A Multivariate Logit Approach. The World Bank Economic Review, 14(2), 287-307. doi:10.1093/wber/14.2.287

30. Demirgüç-Kunt, A., \& Detragiache, E. (2011). Basel Core Principles and Bank Soundness: Does Compliance Matter? Journal of Financial Stability, 7(4), 179-190. doi: 10.1016/j.jfs.2010.03.003

31. Demirgüç-Kunt, A., \& Detragiache, E. (2010). Basel Core Principles and Bank Risk: Does Compliance Matter? IMF Working Papers, 10(81), 1. doi:10.5089/9781451982671.001.

32. Demirguc-Kunt, A., \& Huizinga, H. (1999). Determinants of Commercial Bank Interest Margins and Profitability: Some International Evidence. The World Bank Economic Review, 13(2), 379-408. doi:10.1093/wber/13.2.379

33. Demirgüç-Kunt, A., \& Huizinga, H. (2000). Financial Structure and Bank Profitability. World Bank Policy Research Working Paper, (2430). doi:10.1596/1813-9450-2430

34. Demirguc-Kunt, A., \& Levine, R. (2008). Finance, Financial Sector Policies, And Long-Run Growth. Policy Research Working Papers. doi:10.1596/1813-9450-4469

35. Demirguc-Kunt, A., Detragiache, E., \& Tressel, T. (2006). Banking on The Principles: Compliance with Basel Core Principles and Bank Soundness. Policy Research Working Papers. doi:10.1596/1813-94503954

36. Diaconu, R. I., \& Oanea, D. C. (2014). The Main Determinants of Bank's Stability. Evidence from Romanian Banking Sector. Procedia Economics and Finance, 16, 329-335. doi: 10.1016/s22125671(14)00810-7

37. Dietrich, A., \& Wanzenried, G. (2011). Determinants of Bank Profitability before and during the Crisis: Evidence from Switzerland. Journal of International Financial Markets, Institutions and Money, 21(3), 307-327. doi: 10.1016/j.intfin.2010.11.002

38. Doyran, M. A. (2012). The impact of market structures on financial institution performance. ASBBS Proceedings, 19(1), 247.

39. European Central Bank. Retrieved from: https://www.ecb.europa.eu/pub/pdf/ annex/ ecb.fcdb20170731.en.xlsx (Accessed 21, August 2018).

40. FDIC RMS Manual of Examination Policies (2019). [online] Available at: https://www.fdic.gov/regulations/safety/manual/section7-1.pdf [Accessed 9 Jan. 2019].

41. García-Herrero, A., Gavilá, S., \& Santabárbara, D. (2009). What explains the low profitability of Chinese banks? Journal of Banking \& Finance, 33(11), 2080-2092. doi:10.1016/j.jbankfin.2009.05.005

42. Goddard, J., Molyneux, P., \& Wilson, J. O. (2004). The Profitability of European banks: a Cross Sectional and Dynamic Panel Analysis. The Manchester School, 72(3), 363-381. doi:10.1111/j.14679957.2004.00397.x

43. Evanoff, D. D., \& Fortier, D. L. (1988). Reevaluation of the Structure-Conduct-Performance Paradigm in Banking. Journal of Financial Services Research, 1(3), 277-294. doi:10.1007/bf00114854

44. Gambacorta, L. (2008). How do Banks Set Interest Rates? European Economic Review, 52(5), 792-819. doi:10.1016/j.euroecorev.2007.06.022

45. Guru, B. K., Staunton, J., \& Balashanmugam, B. (2002). Determinants of Commercial Bank Profitability in Malaysia. Journal of Money, Credit, and Banking, 17(1), 69-82.

46. Havrylchyk, O., \& Jurzyk, E. M. (2006). Profitability of Foreign Banks in Central and Eastern Europe: Does the Entry Mode Matter? SSRN Electronic Journal. doi:10.2139/ssrn.965735

47. Hays, F. H., De Lurgio, S. A., \& Gilbert, A. H. (2009). Efficiency Ratios and Community Bank Performance. Journal of Finance and Accountancy, 1(1), 1-15. Available on line https://www.aabri.com/ manuscripts/09227.pdf

48. Huang, T. H., Chiang, D. L., \& Lin, C. L. (2018). The effect of bank mergers on competitive conditions and cost efficiencies in Taiwan-a simulation analysis.

49. Jiménez, G., Lopez, J. A., \& Saurina, J. (2013). How does competition affect bank risk-taking? Journal of Financial Stability, 9(2), 185-195. doi:10.1016/j.jfs.2013.02.004

50. Lloyd-Williams, D. M., Molyneux, P., \& Thornton, J. (1994). Market Structure and Performance in Spanish Banking. Journal of Banking \& Finance, 18(3), 433-443. doi:10.1016/0378-4266(94)90002-7 
51. Kasman, S., Vardar, G., \& Tunç, G. (2011). The Impact of Interest Rate and Exchange Rate Volatility on Banks' Stock Returns and Volatility: Evidence from Turkey. Economic Modelling, 28(3),1328-1334. doi: 10.1016/j.econmod.2011.01.015.

52. Kosmidou, K. (2008). The Determinants of Banks' Profits in Greece During the Period Of EU Financial Integration. Managerial finance, 34(3), 146-159. Doi: 10.1108/03074350810848036 .

53. Kosmidou, K., Tanna, S., \& Pasiouras, F. (2005, June). Determinants of Profitability of Domestic UK Commercial Banks: Panel Evidence from the Period 1995-2002. In Money Macro and Finance (MMF) Research Group Conference, 45, 1-27.

54. Luehrman, T. A. (1991). Exchange Rate Changes and the Distribution of Industry Value. Journal of International Business Studies, 22, 619-649.

55. Mirzaei, A., Moore, T., \& Liu, G. (2013). Does Market Structure Matter on Banks' Profitability and Stability? Emerging vs. Advanced Economies. Journal of Banking \& Finance, 37(8), 2920-2937, doi: 10.1016/j.jbankfin.2013.04.031.

56. Molyneux, P., \& Forbes, W. (1995). Market structure and performance in European banking. Applied Economics, 27(2), 155-159, doi:10.1080/00036849500000018.

57. Molyneux, P., \& Thornton, J. (1992). Determinants of European bank Profitability: A note. Journal of Banking \& Finance, 16(6), 1173-1178, doi:10.1016/0378-4266(92)90065-8.

58. Munteanu, I. (2012). Bank Liquidity and its Determinants in Romania. Procedia Economics and Finance, 3, 993-998. doi:10.1016/s2212-5671(12)00263-8

59. Papadopoulos, S. (2004). Market structure, performance and efficiency in European banking. International Journal of commerce and Management, 14(1), 79-100. doi:10.1108/10569210480000175

60. Pasiouras, F., \& Kosmidou, K. (2007). Factors influencing the profitability of domestic and foreign commercial banks in the European Union. Research in International Business and Finance, 21(2), 222237, doi: 10.1016/j.ribaf.2006.03.007.

61. Perry, P. (1992). Do Banks Gain or Lose from Inflation? Journal of Retail Banking, 14(2), 25-31.

62. Petria, N., Capraru, B., \& Ihnatov, I. (2015). Determinants of Banks' Profitability: Evidence from EU 27 Banking systems. Procedia Economics and Finance, 20, 518-524, doi: 10.1016/S2212-5671(15)00104-5.

63. Quagliariello, M. (2007). Banks' Riskiness over the Business Cycle: A Panel Analysis on Italian Intermediaries. Applied Financial Economics, 17(2), 119-138. doi:10.1080/09603100500486501

64. Revell, J. (1979). Inflation \& Financial Institutions. Financial Times Limited.

65. Quagliariello, M. (2009). Stress-testing the Banking System. New York: Cambridge University Press, pages 38-40.

66. Sathye, S., \& Sathye, M. (2004). Structure, Conduct and Performance Relationship in Indian Banking. Journal of Indian School of Political Economy, 16(1), 1-11.

67. Schaeck, K., \& Cihák, M. (2013). Competition, Efficiency, and Stability in Banking. Financial Management, 43(1), 215-241. doi:10.1111/fima.12010

68. Short, B. K. (1979). The relation between commercial bank profit rates and banking concentration in Canada, Western Europe, and Japan. Journal of Banking \& Finance, 3(3), 209-219. doi:10.1016/03784266(79)90016-5

69. Smirlock, M. (1985). Evidence on the (Non) Relationship between Concentration and Profitability in Banking. Journal of Money, Credit and Banking, 17(1), 69. doi:10.2307/1992507

70. Staikouras, C. K., \& Wood, G. E. (2004). The Determinants of European Bank Profitability. International Business and Economics Research Journal, 3, 57-68.

71. Sturm, J. E., \& Williams, B. (2008). Characteristics Determining the Efficiency of Foreign Banks in Australia. Journal of Banking \& Finance, 32(11), 2346-2360. doi: 10.1016/j.jbankfin.2007.12.029

72. Sufian, F. (2011). Profitability of the Korean Banking Sector: Panel Evidence on Bank-Specific and Macroeconomic Determinants. Journal of economics and management, 7(1), 43-72.

73. Sufian, F., \& Chong, R. R. (2008). Determinants of Bank Profitability in A Developing Economy: Empirical Evidence from the Philippines. Asian Academy of Management Journal of Accounting \& Finance, 4(2).

74. Trujillo-Ponce, A. (2012). What determines the profitability of banks? Evidence from Spain. Accounting \& Finance, 53(2), 561-586. doi:10.1111/j.1467-629x.2011. 00466.x

75. Vazquez, F., Tabak, B. M., \& Souto, M. (2012). A macro stress test model of credit risk for the Brazilian banking sector. Journal of Financial Stability, 8(2), 69-83. doi: 10.1016/j.jfs.2011.05.002 
76. Uhde, A., \& Heimeshoff, U. (2009). Consolidation in Banking and Financial Stability in Europe: Empirical Evidence. Journal of Banking \& Finance, 33(7), 1299-1311, doi: 10.1016/j.jbankfin.2009.01.006.

\section{Footnotes Page}

1. Part 1, A framework for assessing financial stability, Maurizio Trapanese (Bank of Italy).

2. Full sample (All banking groups / stand-alone banks irrespective of their accounting / supervisory reporting framework). Domestic banking groups and stand-alone banks, foreign (EU and non-EU) controlled subsidiaries and foreign (EU and non-EU) controlled branches.

3. Full sample (All banking groups / stand-alone banks irrespective of their accounting / supervisory reporting framework). Domestic banking groups and stand-alone banks, foreign (EU and non-EU) controlled subsidiaries and foreign (EU and non-EU) controlled branches.

4. Full sample (All banking groups / stand-alone banks irrespective of their accounting / supervisory reporting framework). Domestic banking groups and stand-alone banks, foreign (EU and non-EU) controlled subsidiaries and foreign (EU and non-EU) controlled branches.

5. Dataset Source : ${ }^{[1]}$ Oesterreichische Nationalbank (Austria), ${ }^{[2]}$ Banque Nationale de Belgique (Belgium), ${ }^{[3]}$ Central Bank of Cyprus, ${ }^{[4]}$ Deutsche Bundesbank (Germany), ${ }^{[5]}$ Bank of Estonia, ${ }^{[6]}$ Banco de Espana (Spain), ${ }^{[7]}$ Bank of Finland (Finland), ${ }^{[8]}$ Banque de France (France), ${ }^{[9]}$ Bank of Greece (Greece) (GR2), ${ }^{[10]}$ Central Bank of Ireland (Ireland), ${ }^{[11]}$ Banca d Italia (Italy), ${ }^{[12]}$ Bank of Lithuania, ${ }^{[13]}$ Banque centrale du Luxembourg, ${ }^{[14]}$ Bank of Latvia, ${ }^{[15]}$ Central Bank of Malta, ${ }^{[16]}$ Nederlandse Bank (Netherlands), ${ }^{[17]}$ Banco de Portugal (Portugal), ${ }^{[18]}$ Bank of Slovenia, ${ }^{[19]}$ National Bank of Slovakia

6. Full sample (All banking groups / stand-alone banks irrespective of their accounting / supervisory reporting framework). Domestic banking groups and stand-alone banks, foreign (EU and non-EU) controlled subsidiaries and foreign (EU and non-EU) controlled branches.

7. Full sample (All banking groups / stand-alone banks irrespective of their accounting / supervisory reporting framework). Domestic banking groups and stand-alone banks, foreign (EU and non-EU) controlled subsidiaries and foreign (EU and non-EU) controlled branches.

8. Full sample (All banking groups / stand-alone banks irrespective of their accounting / supervisory reporting framework). Domestic banking groups and stand-alone banks, foreign (EU and non-EU) controlled subsidiaries and foreign (EU and non-EU) controlled branches.

9. https://www.ecb.europa.eu/pub/pdf/annex/ecb.fcdb20170731.en.xlsx

10. The references are mentioned in European Central Bank (Jul 31, 2017), https://www.ecb.europa.eu/pub/pdf/annex/ecb.fcdb20170731.en.xlsx (date of visiting 21). 